\title{
Panicum sect. Dichotomiflora (Hitchc. \& Chase) Honda e P. sect. Virgata Hitchc. \& Chase ex Pilg. (Poaceae: Panicoideae: Paniceae) no Brasil ${ }^{1}$
}

\author{
Adriana Guglieri' ${ }^{2,5}$, Hilda Maria Longhi-Wagner ${ }^{3}$ e Fernando O. Zuloaga ${ }^{4}$
}

Recebido em 20/12/2005. Aceito em 10/02/2007

\begin{abstract}
RESUMO - (Panicum sect. Dichotomiflora (Hitchc. \& Chase) Honda e P. sect. Virgata Hitchc. \& Chase ex Pilg. (Poaceae: Panicoideae: Paniceae) no Brasil). Panicum L. subg. Panicum inclui cerca de 100 espécies predominantemente tropicais. Deste total, aproximadamente 50 espécies são americanas e ocorrem desde o Canadá até Argentina, Uruguai e Brasil. Está representado no Brasil por 30 espécies, três delas sem seção definida, e as demais distribuídas entre $P$. sect. Dichotomiflora (Hitchc. \& Chase) Honda, P. sect. Panicum, P. sect. Rudgeana (Hitchc.) Zuloaga, P. sect. Urvilleana (Hitchc. \& Chase) Pilger e P. sect. Virgata Hitchc. \& Chase ex Pilg. O presente trabalho tem como objetivo fornecer meios para a identificação das espécies de Panicum sect. Dichotomiflora e P. sect. Virgata nativas e exóticas naturalizadas ocorrentes no Brasil, contribuindo para o conhecimento da flora agrostológica brasileira e fornecendo subsídios para pesquisas em outras áreas. Para este estudo foram realizadas revisão bibliográfica, revisão de herbários, coletas e observação de populações no campo, bem como análise da superfície do segundo antécio em Microscopia Eletrônica de Varredura (MEV). Panicum sect. Dichotomiflora inclui cerca de 11 espécies neotropicais, das quais seis têm ocorrência confirmada no Brasil e ocorrem principalmente em ambientes úmidos como brejos e margens de cursos d'água. Panicum sect. Virgata inclui aproximadamente oito espécies neotropicais, das quais quatro ocorrem no Brasil, em ambientes variados tais como cerrado, campos e brejos. O trabalho apresenta chaves para identificação dos grupos taxonômicos atualmente aceitos em Panicum e ocorrentes no Brasil, tabela comparativa das seções de Panicum subg. Panicum, bem como chave para identificação, descrições, dados de distribuição geográfica e da superfície do segundo antécio em MEV, ilustrações e fotomicrografias das espécies de $P$. sect. Dichotomiflora e $P$. sect. Virgata confirmadas para o país.
\end{abstract}

Palavras-chave: Brasil, Gramineae, Panicum, taxonomia

\begin{abstract}
Panicum sect. Dichotomiflora (Hitchc. \& Chase) Honda and P. sect. Virgata Hitchc. \& Chase ex Pilg. (Poaceae: Panicoideae: Paniceae) in Brazil). Panicum L. subg. Panicum includes nearly 100, mostly tropical and subtropical species; of these, 50 taxa are American, ranging from Canada to Brazil, Argentina and Uruguay. A total of 30 species are present in Brazil, three without a defined section and 27 included in P. sect. Dichotomiflora (Hitchc. \& Chase) Honda, P. sect. Panicum, P. sect. Rudgeana (Hitchc.) Zuloaga, $P$. sect. Urvilleana (Hitchc. \& Chase) Pilger and $P$. sect. Virgata Hitchc. \& Chase ex Pilg. The aim of this paper is to present a systematic study of native and naturalized species of $P$. sect. Dichotomiflora and $P$. sect. Virgata in Brazil: Panicum sect. Dichotomiflora has 6 species in the country (of a total of 11 species in the section), growing in wet habitats suh as swamps or river banks. Panicum sect. Virgata includes 4 species in Brazil, present in habitats such as grasslands "cerrado" and swamps. Keys to the species of both sections are given, as well as tables, morphological descriptions, illustrations, and scanning electron micrographs of the upper anthecium surface.
\end{abstract}

Key words: Brazil, Gramineae, Panicum, taxonomy

\section{Introdução}

O gênero Panicum, em obras agrostológicas mais antigas, como Raddi (1823), Nees (1829) e Döll (1877), incluía um grande número de espécies pertencentes atualmente a outros gêneros da tribo Paniceae.

Clayton \& Renvoize (1986) estimaram cerca de 470 espécies para o gênero e Watson \& Dallwitz (1992) cerca de 370 espécies. Segundo a circunscrição proposta por Zuloaga (1987a), o gênero Panicum incluiria ca. 600 espécies distribuídas em $P$. subg. Agrostoides (Hitchc.) Zuloaga, P. subg. Dichanthelium Hitchc. \& Chase, P. subg. Megathyrsus Pilger, P. subg. Panicum, P. subg. Phanopyrum (Raf.) Pilger e P. subg. Steinchisma (Raf.) Zuloaga. De acordo com o mesmo autor, $P$. subg.

\footnotetext{
Parte da tese de Doutorado da primeira Autora no PPG Botânica da Universidade Federal do Rio Grande do Sul

2 Universidade Federal de Mato Grosso do Sul, Centro de Ciências Biológicas e da Saúde, Departamernto de Biologia, C. Postal 549, 70070-900 Campo Grande, MS, Brasil

3 Universidade Federal do Rio Grande do Sul, Departamento Botânica, Av. Bento Gonçalves 9500, Bloco IV, prédio 43433, sala 214, 91570-950 Porto Alegre, RS, Brasil

3 Instituto de Botánica Darwinion, Casilla de Correo 22, B1642HYD, San Isidro, Buenos Aires, Argentina

4 Autor para correspondência: adrianaguglieri@ig.com.br
} 
Panicum incluiria P. sect. Dichotomiflora (Hitchc. \& Chase) Honda (com sete espécies americanas), P. sect. Panicum (22), P. sect. Repentia Stapf (12), $P$. sect. Rudgeana (Hitchc.) Zuloaga (seis) e $P$. sect. Urvilleana (Hitchc. \& Chase) Pilger (três). Porém, a circunscrição aceita por Clayton \& Renvoize (1986) ainda era mais ampla que a atualmente aceita.

Ao longo do tempo, estudos utilizando diferentes abordagens levaram ao desmembramento do gênero Panicum, propondo a elevação de alguns subgêneros propostos por Zuloaga (1987a) à categoria de gêneros, tais como Steinchisma Raf. (Zuloaga et al. 1998; Zuloaga \& Morrone 2003); Dichanthelium (Hitchc. \& Chase) Gould (Gould 1974; Aliscioni et al. 2003; Zuloaga \& Morrone 2003); Phanopyrum (Raf.) Nash (Aliscioni et al. 2003; Zuloaga \& Morrone 2003) e Megathyrsus Pilg. (Simon \& Jacobs 2003).

Considerando a circunscrição de Panicum subg. Panicum, ocorreram apenas algumas modificações em sua classificação interna, tais como a transferência de algumas espécies de $P$. sect. Repentia para $P$. sect. Dichotomiflora, por Aliscioni et al. (2003). Aliscioni et al. (2003) reconheceram $P$. subg. Panicum como monofilético, incluindo $P$. sect. Dichotomiflora, $P$. sect. Panicum, $P$. sect. Rudgeana, P. sect. Urvilleana e $P$. sect. Virgata Hitchc. \& Chase ex Pilg. No mesmo trabalho, Aliscioni et al. (2003) não conseguiram definir a posição de algumas espécies, que permaneceram sem seção definida.

Deste modo, de acordo com a circunscrição aceita no presente trabalho (Aliscioni et al. 2003), o gênero Panicum compreende cerca de 400 espécies predominantemente pantropicais, algumas das quais se estendem até as regiões subtropicais e temperadas. Convém salientar que Aliscioni et al. (2003) sugeriram que Panicum poderia ser restrito ao subgênero típico, mas seu trabalho não é conclusivo a este respeito e certamente novos estudos serão realizados para definir este tema.

Por sua vez, Panicum subg. Panicum compreende cerca de 100 espécies, que se distribuem desde o Canadá até o Uruguai e Brasil, com ocorrência confirmada em alguns países da Europa e Ásia e por toda a África e Oceania (Häfliger \& Scholz 1980). Foram citadas 52 espécies de $P$. subg. Panicum para os neotrópicos (Aliscioni et al. 2003), das quais 30 confirmadas para o Brasil (A. Guglieri, dados não publicados) ocorrendo em todas as regiões brasileiras, em ambientes variados, como cerrados, campos secos e úmidos, brejos, margens de cursos d'água, dunas e locais alterados.
Nos últimos anos, foram publicados vários trabalhos que tratam da revisão de alguns subgêneros e seções de Panicum, tais como Zuloaga (1987b), Zuloaga \& Morrone (1996), Zuloaga et al. (1986; 1992; 1993), entre outros. Porém, o gênero Panicum no Brasil foi pouco estudado e o levantamento do mesmo tem sido feito em algumas floras regionais, como aquelas apresentadas por Smith et al. (1982), Renvoize (1984; 1988), Guglieri \& Longhi-Wagner (2000) e Zuloaga et al. (2001).

Ao longo do tempo, muitos autores mencionaram a importância taxonômica de diferentes caracteres relacionados ao segundo antécio em espécies de gramíneas, incluindo àquelas da tribo Paniceae, bem como de Panicum.

Blake (1958), analisando o segundo antécio em microscopia óptica, salientou caracteres relativos à forma e à presença de rugosidade em gêneros da tribo Paniceae, incluindo Panicum.

Hsu (1965 apud Zuloaga et al. 1987a) e Clark \& Gould (1975) examinaram o segundo antécio de espécies de Panicum em Microscopia Eletrônica de Varredura, salientando caracteres referentes à superfície do mesmo, tais como presença e localização de papilas, tricomas microscópicos bicelulares, estômatos e corpos silicosos.

Zuloaga (1985; 1987a; b), Zuloaga \& Sendulsky (1988), Zuloaga et al. $(1992 ; 1993)$ e Zuloaga \& Morrone (1996) incluíram a análise da superfície do segundo antécio em seus estudos sobre diferentes subgêneros (muitos dos quais aceitos atualmente como gêneros) e seções de Panicum, em MEV. Analisaram especialmente a presença ou não de tricomas unicelulares uncinados, tricomas microscópicos bicelulares, corpos silicosos, e a presença e tipo de papilas.

\section{Material e métodos}

O principal objetivo deste trabalho é fornecer meios para a identificação das espécies de Panicum sect. Dichotomiflora e P. sect. Virgata nativas e exóticas naturalizadas ocorrentes no Brasil, contribuindo para o conhecimento da flora agrostológica brasileira e fornecendo subsídios para pesquisas em outras áreas.

Este estudo foi baseado em revisão bibliográfica, revisão de herbários, coletas e observação de populações no campo, e análise de caracteres exomorfológicos, incluindo a superfície do segundo antécio em Microscópio Eletrônico de Varredura (MEV). 
Foram revisados os seguintes herbários, citados pela sua sigla internacional, conforme Holmgren \& Holmgren (2005): ALCB, B, BA, BAA, BAB, BAF, BHCB, BLA, BOTU, CEN, CEPEC, CNPO, CESJ, COL, COR, CORD, CVRD, EAC, ESA, ESAL, F, FLOR, FUEL, G, GH, HAMAB, HAS, HCB, HBR, HERBACRUZ, HEPH, HRB, HRCB, HST, HUCS, HUEFS, HUFU, HUI, HUM, HURG, HUPF, IAC, IAN, IBGE, ICN, INPA, INTA, IPA, ISC, JEPS, JPB, K, LA, LE, LIL, LP, LPB, M, MAC, MBM, MBML, MEXU, MG, MO, MPUC, MUFAL, MY, NY, P, PACA, PAMG, PEL, PMSP, R, RB, RFA, RSPF, S, SI, SMDB, SJRP, SP, SPF, SPSF, TEPB, UB, UEC, UFG, UFMT, UPCB, US, USM, UTME, VEN e W. Além destes, foi revisado o herbário Balduíno Rambo, do Museu Regional do Alto Uruguai (Universidade Regional Integrada do Alto Uruguai e das Missões URI), cuja sigla, não oficial, é HERBARA.

Foram realizadas coletas e observação de populações em seu ambiente natural no Distrito Federal e nos Estados de Goiás, Minas Gerais, São Paulo, Paraná, Santa Catarina e Rio Grande do Sul, procurando abranger as áreas de maior diversidade do gênero no Brasil.

Caracteres exomorfológicos, vegetativos e reprodutivos, de relevância taxonômica, foram selecionados e lançados no Sistema Delta (versão para MS-Windows 95/NT, pacote Delt32), elaborando-se uma lista de caracteres e seus estados, a qual foi utilizada na análise do material selecionado para observação e serviu como base para as descrições das espécies. Para esta análise mais detalhada, foram selecionados dez exemplares de cada espécie, sempre que havia material suficiente, de modo a abranger toda a variação morfológica, bem como diferentes áreas de coleta e habitats.

A terminologia para forma e indumento das estruturas seguiu Radford et al. (1974). A abreviatura dos autores das espécies seguiu Brummitt \& Powell (1992). As citações de "Opus Princeps" foram feitas de acordo com Stafleu \& Cowan (1976-1988) e as citações de periódicos de acordo com Bridson \& Smith (1991).

Foram incluídas em sinonímia apenas as espécies de Panicum citadas anteriormente para o Brasil. Os exemplares-tipo examinados foram indicados por “!”.

Referências à distribuição geográfica geral das espécies seguem Zuloaga \& Morrone (2003), enquanto que sua distribuição no Brasil aparece no material selecionado, que inclui um exemplar por estado. Em certos casos, mais de um exemplar foi citado, para incluir o material utilizado nas ilustrações e nas fotomicrografias em MEV. Dados de ambiente foram baseados em informações contidas nas etiquetas de herbário e em observações feitas diretamente no campo.

Para a análise da superfície do segundo antécio ao Microscópio Eletrônico de Varredura (MEV), foram selecionados dois e em casos de maior variabilidade, três exemplares de cada espécie. Os antécios, sem prévio tratamento foram aderidos a "stubs", com auxílio de fita-carbono dupla face, e metalizados com ouro por cerca de 60 segundos. As amostras foram fotografadas por MEV JSM-6060. Os exemplares utilizados nesta análise encontram-se marcados com um asterisco no material selecionado.

As ilustrações das estruturas reprodutivas foram feitas em câmara clara acoplada a microscópio estereoscópico WILLD M32, enquanto que as ilustrações dos hábitos e das inflorescências foram obtidas a partir de cópias reprográficas das plantas. Foram montadas pranchas com as ilustrações e estas foram cobertas a nanquim, em papel vegetal.

\section{Resultados e discussão}

\section{Panicum L., Sp. Pl.: 55. 1753.}

Plantas cespitosas, com ou sem rizomas, eretas, decumbentes ou estoloníferas. Prefoliação convoluta ou conduplicada. Lâminas foliares lineares a ovallanceoladas, mais raramente filiformes, quilhadas ou não, ápice agudo, base atenuada, arredondada, subcordada ou cordada, amplexicaule ou não, com ou sem pseudopecíolo, glabras ou com indumento variado. Lígula membranosa ou membranoso-ciliada, mais raramente pilosa ou ausente. Panícula com as espiguetas dispostas irregularmente ao longo de todos os ramos, laxa a contraída, ou panículas racemosas, com as espiguetas dispostas unilateralmente sobre a ráquis. Espiguetas acrótonas, com dois antécios, o primeiro membranoso, neutro ou com flor estaminada (estames 3), o segundo coriáceo ou subcoriáceo com flor bissexuada [estames (2)3], mais raramente com três antécios (Panicum quadriglume), sendo o primeiro neutro e membranoso, o segundo com flor estaminada e também membranoso, e o terceiro com flor bissexuada e coriáceo (correspondente ao segundo das demais espécies); espiguetas estreito-lanceoladas, ovóide-lanceoladas, ovóides ou obovóides; ráquila articulada abaixo das glumas, estas membranosas, caducas com os antécios maduros, raramente com uma 
segunda zona de articulação abaixo do segundo antécio, este caindo antes do restante da espigueta; gluma inferior caracteristicamente menor que a gluma superior (exceto $P$. racemosum, na qual, às vezes, a gluma inferior é quase do mesmo comprimento da gluma superior), (0)1-5(7-11)-nervada, glabra ou com indumento variado; gluma superior de comprimento variável, subigual ao do restante da espigueta, 3-7(9-11)-nervada, glabra ou com indumento variado; lema 3-7(9-11)-nervado, glabro ou com indumento variado; pálea presente ou ausente; segundo antécio com lema liso ou transversalmente rugoso, papiloso ou não, glabro ou com indumento variado, palhete, castanho ou negro na maturação; pálea biquilhada, de consistência igual ao lema; lodículas 2. Estames (2)3. Cariopse ovóide ou obovóide, palhete a castanha, hilo oval a oboval.

Espécie-tipo: Panicum miliaceum L.

Chave para identificação dos grupos taxonômicos de Panicum ocorrentes no Brasil

1. Panícula com as espiguetas dispostas unilateralmente sobre os ramos

2. Segundo antécio de comprimento inferior ao da gluma superior e ao lema do primeiro antécio, com estípite curto na base, sem papilas ou tricomas unicelulares ganchosos P. sect. Stolonifera

2. Segundo antécio de comprimento subigual ao da gluma superior e ao lema do primeiro antécio, sem estípite na base, com papilas simples regularmente distribuídas em toda a superfície, com ou sem tricomas unicelulares ganchosos em direção ao ápice do lema e da pálea

3. Cariopse negra; segundo antécio crustáceo, com papilas simples em direção ao ápice, sem tricomas unicelulares uncinados, e sem corpos silicosos P. scabridum

3. Cariopse palhete a castanha; segundo antécio membranoso a cartilaginoso, com papilas simples em toda a superfície, e com tricomas unicelulares uncinados e corpos silicosos em direção ao ápice P. sect. Laxa

1. Panícula com as espiguetas dispostas irregularmente ao longo dos ramos

4. Glumas com o ápice aristulado . P. aristellum

4. Glumas com o ápice não aristulado

5. Panícula com ramos tipicamente verticilados P. sect. Megista

5. Panícula com ramos alternos ou opostos, ou apenas a ramificação mais inferior verticilada

6. Inflorescências contraídas, com 2-25 espiguetas aproximadamente; lâminas foliares filiformes P. sect. Tenera

6. Inflorescências contraídas a laxas, com 30 ou mais espiguetas; lâminas foliares linearlanceoladas a lanceoladas, raramente filiformes

7. Segundo antécio biconvexo, densamente piloso no ápice e na base, com tricomas enrolados ou torcidos P. sect. Discrepantia

7. Segundo antécio plano-convexo, glabro ou piloso em toda a superfície ou apenas na base, com tricomas retos

8. Lâminas foliares quilhadas; colmos de secção elíptica, maciços ou com lúmen escasso

9. Espiguetas 2,3-3,2 mm compr.; panícula piramidal, 25,0-60,0×7,0-20,0 cm; segundo antécio glabro e sem papilas P. sect. Prionitia

9. Espiguetas 2,8-3,8 mm compr.; panícula de contorno oblongo, 17,0-30,0× 3,0-6,0 cm; segundo antécio piloso no ápice, e com papilas distribuídas em toda a superfície P. sect. Valida

8. Lâminas foliares não quilhadas; colmos de secção circular, ocos, raramente maciços

10. Plantas trepadoras e apoiantes na vegetação, bambusóides; glumas e lema do primeiro antécio lanosos ao longo das margens superiores

11. Gluma superior e lema do primeiro antécio 5-nervados P. longipedicellatum 11. Gluma superior e lema do primeiro antécio 9-11-nervados P. penicillatum

10. Plantas eretas, às vezes decumbentes, não trepadoras ou apoiantes na vegetação, não bambusóides; glumas e lema do primeiro antécio glabros ao longo das margens superiores 
12. Segundo antécio mucronado no ápice; espiguetas das inflorescências terminais com glumas e lema do primeiro antécio glabros, e das inflorescências axilares com glumas e lema do primeiro antécio pilosos ou hirsutos (exceto $P$. ovuliferum, que apresenta espiguetas das inflorescências terminais e axilares semelhantes, com glumas e lema do primeiro antécio glabros ou esparsamente pilosos no ápice) ....P. sect. Cordovensia

12. Segundo antécio não mucronado; espiguetas das inflorescências terminais e axilares semelhantes, com ou sem indumento

13. Gluma inferior 1/7-1/5 do comprimento da espigueta; segundo antécio com tricomas pluricelulares em toda a superfície P. sect. Parviglumia

13. Gluma inferior $1 / 4-4 / 5$ do comprimento da espigueta; segundo antécio glabro ou com tricomas pluricelulares apenas na base

14. Lígula membranoso-ciliada ou pilosa; gluma superior e lema do primeiro antécio (5-)7-13(-15)-nervados; segundo antécio com papilas simples e/ou compostas apenas no ápice do lema e da pálea, raramente em toda a superfície, sem tricomas microscópicos bicelulares P. subg. Panicum

14. Lígula membranosa; gluma superior e lema do primeiro antécio 3-5(-7)-nervados; segundo antécio com papilas simples regularmente distribuídas em toda a superfície ou sem as mesmas, com ou sem tricomas microscópicos bicelulares

15. Plantas cespitosas, não flutuantes ou apoiantes na vegetação, eretas, raramente decumbentes, formando touceiras densas; lâminas foliares pungentes, as basais enroladas quando secas; lígula ausente ou presente, quando presente, região ligular definida ou não externamente, aurículas presentes ou ausentes; gluma superior 5-7-nervada

P. sect. Lorea

15. Plantas estoloníferas a rizomatosas, flutuantes ou apoiantes na vegetação a decumbentes, raramente eretas, nunca formando touceiras densas; lâminas foliares não pungentes, as basais não enroladas quando secas; lígula presente, região ligular definida externamente, aurículas ausentes; gluma superior 5-nervada

16. Plantas robustas, $100,0-300,0 \mathrm{~cm}$, estoloníferas, flutuantes; bainhas com aerênquima; lâminas foliares 50,0-100,0× 2,5-6,0 cm; inflorescências 30-70 cm comprimento, antécio superior glabro

P. grande

16. Plantas herbáceas, até $100,0(-120,0) \mathrm{cm}$ compr., sem estolões, não flutuantes; bainhas sem aerênquima; lâminas foliares até 20,0×2,0 cm; inflorescências até $30,0 \mathrm{~cm}$ compr., antécio superior com micropêlos bicelulares

17. Segundo antécio levemente rugoso P. sect. Monticola

17. Segundo antécio liso

18. Glumas separadas por um entrenó conspícuo, a superior notadamente inserida acima da inferior; espiguetas longamente elipsóides P. haenkeanum

18. Glumas separadas por um entrenó inconspícuo, a superior e a inferior aparentemente inseridas no mesmo ponto; espiguetas elipsóides a obovóides 


\section{Panicum subg. Panicum}

Plantas eretas ou decumbentes, não trepadoras, herbáceas. Lâminas foliares lineares, planas, não quilhadas, com região ligular bem diferenciada abaxialmente, sem pseudopecíolo. Inflorescência em panícula laxa ou contraída, nunca racemosa. Glumas obtusas, agudas ou acuminadas, nunca aristuladas; gluma superior e lema do primeiro antécio (5-)7-13(-15)-nervados; segundo antécio sem rugosidades transversais; plantas $\mathrm{C}_{4} \mathrm{NAD}-\mathrm{ME}$

Os principais caracteres utilizados na diferenciação das seções de Panicum subg. Panicum, e seus respectivos estados são apresentadas na Tab. 1.

I. Panicum subg. Panicum sect. Dichotomiflora (Hitchc. \& Chase) Honda

A seção inclui cerca de 11 espécies neotropicais (Aliscioni et al. 2003). Destas, seis têm ocorrência confirmada para o Brasil.

Chave para as espécies de Panicum subg. Panicum sect. Dichotomiflora ocorrentes no Brasil

1. Colmos com aerênquima; espiguetas estreito-lanceoladas, (3,7-)4,6-5,4 mm compr.; plantas aquáticas

3. P. elephantipes

1. Colmos sem aerênquima; espiguetas lanceoladas a ovóide-lanceoladas, (1,9-)2,4-3,5 mm compr.; plantas geralmente de ambientes úmidos.

2. Plantas eretas, anuais, sem rizomas

2. P. dichotomiflorum

2. Plantas decumbentes, perenes, com rizomas (às vezes plantas eretas em P. repens).

3. Gluma inferior de ápice obtuso; segundo antécio com estípite de $0,2-0,4 \mathrm{~mm}$ compr. ..... 5. P. pedersenii

3. Gluma inferior de ápice agudo, acuminado ou truncado; segundo antécio sem estípite

4. Gluma inferior de ápice truncado 6. P. repens

4. Gluma inferior de ápice agudo a acuminado

5. Plantas com rizomas finos de entrenós longos, não escamosos; lâminas foliares planas, 0,4-1,2 cm larg.; panícula laxa, (4,0-)6,0-14,0(-22,5) cm larg. 1. P. aquaticum

5. Plantas com rizomas grossos de entrenós curtos, escamosos; lâminas foliares geralmente involutas, raramente planas, $0,1-0,3(-0,5) \mathrm{cm}$ larg.; panícula subcontraída, mais raramente laxa, 1,0-6,0 cm larg.

4. P. gouinii

1. Panicum aquaticum Poir. in Lam., Encycl., Suppl. 4: 281. 1816. Tipo: Porto Rico, s.d., Anon s.n. (holótipo: P!; isótipo: US-80463! (fragm.).

P. hygrophilum Salzm. ex Steud., Syn. pl. glumac. 1: 71. 1853. Tipo: Brasil, Bahia, in humidis, Salzmann s.n. (holótipo: P!; isótipos: G!, GH!, MO!, US!, W!). Fig. 1-4

Plantas perenes, 25,0-120,0 cm, decumbentes, radicantes nos nós inferiores, com rizomas finos, de 0,2-0,3 cm de diâmetro, entrenós longos, com 2,5-3,5 cm compr., não escamosos; colmos sem aerênquima; nós claros ou escuros, glabros. Prefoliação convoluta. Bainhas foliares glabras ou pilosas, tricomas não tuberculados, esparsos, margem glabra ou pilosa; colo glabro. Lâminas foliares (2,5-)10,0-25,0(-32,0)× 0,4-1,2 cm, lineares a linear-lanceoladas, planas, base atenuada, arredondada ou subcordada; face abaxial glabra; face adaxial glabra ou pilosa, tricomas não tuberculados, esparsos a densos; margens lisas ou escabras, tricomas longos ausentes. Lígula membranoso-ciliada, $(0,2-) 0,4-0,7(-1,2) \mathrm{mm}$ compr., sem tricomas longos atrás, na base da face ventral da lâmina. Panículas
$(4,0-) 6,0-16,5(-24,0) \times(4,0-) 6,0-14,0(-22,5) \mathrm{cm}$, laxas, ramos inferiores alternos, divergentes do eixo principal; axilas glabras; ráquis glabra; pedicelos glabros ou escabros; panículas axilares ausentes. Espiguetas 2,7-3,5×0,6-1,4 mm, lanceoladas a ovóides-lanceoladas, com dois antécios; glumas e lema do primeiro antécio palhetes ou esverdeados, com ou sem manchas vináceas; gluma inferior (0,8-)1,2-1,7 mm compr., 1/3-2/5 do comprimento da espigueta, ápice agudo, 1-3-nervada, glabra; gluma superior 2,5-3,4 mm compr., ápice agudo a acuminado, 7-9-nervada, persistente na espigueta madura, glabra; primeiro antécio neutro ou com flor estaminada; lema 2,5-3,3 mm compr., ápice agudo a acuminado, 9-nervado, glabro; pálea presente, (1,4-)2,2-2,7 mm compr., lanceolada; segundo antécio 1,9-2,4×0,7-0,9 mm, subcoriáceo, papiloso, palhete a castanho na maturação, glabro, sem estípite. Estames 3, anteras 1,2-1,3 mm compr., alaranjadas. Cariopse 1,2-1,4×0,6-0,7 mm, ovóide, castanha, hilo oval.

Material selecionado: BRASIL. Acre: s.mun., s.d., s.col. (IAN 100728). Amazonas: Tefé, 3/XII/1982, Plowman et al. s.n. (UB12574). Bahia: 
Tabela 1. Principais caracteres utilizados na diferenciação das seções de Panicum subg. Panicum e seus estados.

\begin{tabular}{|c|c|c|c|c|c|c|}
\hline & $\begin{array}{l}\text { Panicum sect. } \\
\text { Dichotomiflora }\end{array}$ & $\begin{array}{l}\text { Panicum sect. } \\
\text { Panicum }\end{array}$ & $\begin{array}{l}\text { Panicum sect. } \\
\text { Rudgeana }\end{array}$ & $\begin{array}{l}\text { Panicum sect. } \\
\text { Urvilleana }\end{array}$ & $\begin{array}{c}\text { Panicum sect. } \\
\text { Virgata }\end{array}$ & $\begin{array}{c}\text { Espécies } \\
\text { incertaesedis }\end{array}$ \\
\hline Lígula (tipo) & $\begin{array}{l}\text { membranoso- } \\
\text { ciliada }\end{array}$ & $\begin{array}{l}\text { membranoso- } \\
\text { ciliada }\end{array}$ & $\begin{array}{l}\text { membranoso- } \\
\text { ciliada }\end{array}$ & pilosa & $\begin{array}{l}\text { membranoso- } \\
\text { ciliada }\end{array}$ & $\begin{array}{l}\text { membranoso- } \\
\text { ciliada }\end{array}$ \\
\hline $\begin{array}{r}\text { Glumas e lema } \\
\text { (indumento) }\end{array}$ & glabros & glabros & $\begin{array}{c}\text { glabros ou } \\
\text { com tricomas } \\
\text { 2- }-0,6 \mathrm{~mm} \text { compr.) }\end{array}$ & $\begin{array}{l}\text { com tricomas } \\
(1-5 \mathrm{~mm} \text { compr.) }\end{array}$ & glabros & glabros \\
\hline Entrenó das glumas & inconspícuo* & $\begin{array}{l}\text { geralmente } \\
\text { inconspícuo }\end{array}$ & conspícuo** & inconspícuo & conspícuo & $\begin{array}{l}\text { inconspícuo em } \\
\text { Panicum olyroides }\end{array}$ \\
\hline $\begin{array}{l}\text { Segundo antécio } \\
\text { (indumento) }\end{array}$ & glabro & glabro & glabro & $\begin{array}{l}\text { com tricomas } \\
\text { cilíndricos }\end{array}$ & glabro & $\begin{array}{l}\text { com tricomas } \\
\text { achatados }\end{array}$ \\
\hline $\begin{array}{l}\text { Segundo antécio } \\
\text { (consistência) }\end{array}$ & subcoriáceo & coriáceo & coriáceo & coriáceo & subcoriáceo & coriáceo \\
\hline Estípite (presença) & raramente presente & ausente & presente & ausente & ausente & $\begin{array}{c}\text { ausente em } \\
\text { Panicum olyroides }\end{array}$ \\
\hline Estames (coloração) & alaranjados & violáceos & violáceos & violáceos & violáceos & violáceos \\
\hline
\end{tabular}

*glumas aparentemente inseridas no mesmo ponto; **gluma superior inserida notadamente acima da inferior.

Mucugê, 15/III/1999, Zuloaga \& Morrone 6967 (IBGE, SI). Ceará: Fortaleza, Barra do Cocó, 16/VI/1955, Fernandes et al. s.n. (EAC 1189); Iguatu, 21-22/IV/1934, Swallen 4414 (RB)*. Distrito Federal: Brasília, Parque Nacional, IV/1995, Martins s.n. (IBGE 36101). Espírito Santo: Vitória, Parque Estadual de Setiba, s.d., Gomes 1504 (ICN). Goiás: Corumbá de Goiás, 23/III/1994, Filgueiras 2810 (IBGE). Maranhão: s.mun., 4/IV/1988, Secco \& Rosa 771 (MG). Mato Grosso: Araputanga, 9/V/1995, Hatschbach 62512 (ICN, MBM). Minas Gerais: Belo Horizonte, 1/X/1982, Lopes \& Coeli 80 (BHCB)*; Tiradentes, 26/II/1993, Zuloaga \& Morrone 4729 (IBGE). Pará: Ilha do Marajó, 27/IX/1965, Oliveira 3409 (IAN). Paraíba: Areia, 3/II/1969, Tenório 69-610 (IPA). Paraná: Guaratuba, 12/I/2004, Guglieri et al. 242 (ICN). Rio de Janeiro: Rio de Janeiro, Serra do Medanha, 19/IV/1972, Sucre 8854 (RB, SI). Rio Grande do Norte: s.mun., s.d., Swallen 4830 (IAN). Rio Grande do Sul: Morro Reuter, 30/III/2003, Guglieri et al. 90 (ICN)*; Torres, 2/II/1963, Kappel \&Froner s.n. (RSPF 5193). Santa Catarina: Tubarão, 18/XII/1986, Lerner 2861-A (MPUC). São Paulo: São Paulo, 19/I/2000, Garcia \& Longhi-Wagner 2100 (PMSP).

Distribuição geográfica e habitat: México, América Central, Brasil, Peru, Bolívia, Paraguai e Argentina. Está distribuída nas cinco regiões geográficas do Brasil, e ocorre em brejos, margens de cursos d'água, campos, baixadas, restingas, e locais úmidos em margens de estradas. Apresenta comportamento bastante agressivo, e pode atuar como invasora de culturas e jardins.

Panicum aquaticum não foi citada por Renvoize (1984), Renvoize (1988) e Filgueiras (1995) para a Bahia, Paraná e Goiás, respectivamente, sendo citadas pela primeira vez para estes estados, no presente trabalho.

Assim como Panicum dichotomiflorum Michx., $P$. gouinii E.Fourn., P. pedersenii Zuloaga e P. repens L., $P$ aquaticum é comum em ambientes úmidos. Estas espécies apresentam disposição das folhas, inflorescências e espiguetas semelhantes. Panicum dichotomiflorum diferencia-se das demais pelo hábito ereto, sem rizomas, e pelas espiguetas com gluma inferior obtusa a aguda. Panicum gouinii distinguese pelos rizomas grossos e escamosos, de entrenós curtos, pelas lâminas foliares geralmente involutas, e pelas inflorescências geralmente subcontraídas. Panicum pedersenii e $P$. repens diferenciam-se de $P$. aquaticum principalmente pelo ápice da gluma inferior, que é obtuso, na primeira espécie, e truncado, na segunda.

2. Panicum dichotomiflorum Michx., Fl. bor. amer. 1: 48. 1803. Tipo: Hab. in occidentalibus montium Alleghanis, Michaux s.n. (holótipo: P!; isótipo: $\mathrm{P}$ !). 
P. multiflorum Poir. in Lam., Encycl., Suppl. 4: 282. 1816. Estados Unidos, Carolinas, Bosc s.n. (lectótipo: P!, designado por Hitchcock \& Chase, Contr. U.S. Natl. Herb. 15: 48. 1910)

P. chloroticum Nees ex Trin., Gram. panic.: 236. 1826.

Tipo: Brasil, Mato Grosso, Cuyaba, Paraguay rv., 1829, G.H. von Langsdorff s.n. (holótipo: LE0633.01!; isótipo: K).

Fig. 5-9

Plantas anuais, (14,0-)26,0-94,0(-140,0) cm, eretas, sem rizomas; colmos sem aerênquima; nós claros ou escuros, glabros. Prefoliação convoluta. Bainhas foliares glabras, margem glabra; colo glabro. Lâminas foliares $(1,4-) 5,0-20,0(-26,5) \times(0,2-) 0,5-1,1(-1,3) \mathrm{cm}$, linear-lanceoladas, planas, base atenuada, arredondada ou subcordada; faces abaxial e adaxial glabras; margens lisas ou escabras, tricomas longos ausentes ou presentes, macios e tuberculados, junto à lígula ou no $1 / 3$ inferior da lâmina. Lígula membranoso-ciliada, (0,6-)1,5-2,0 mm compr., sem tricomas longos atrás, na base da face ventral da lâmina. Panículas $(4,0-) 12,0-22,0(-27,5) \times(1,0) 5,0-14,0(-21,0) \mathrm{cm}$, laxas a subcontraídas, ramos inferiores verticiliados ou alternos, divergentes do eixo principal; axilas glabras; ráquis glabra ou escabra; pedicelos escabros; panículas axilares geralmente presentes e similares às terminais. Espiguetas (1,9-)2,4-3,0(-3,3)×0,6-1,2 mm, lanceoladas a ovóide-lanceoladas, com dois antécios; glumas e lema do primeiro antécio palhetes ou esverdeados, com ou sem manchas vináceas; gluma inferior $0,4-1,1(-1,4) \mathrm{mm}$ compr., 1/5-1/3 do comprimento da espigueta, ápice agudo ou obtuso, 1-3-nervada, glabra; gluma superior $(1,8-) 2,3-2,8(-3,3) \mathrm{mm}$ compr., ápice agudo a acuminado, 7-11-nervada, persistente na espigueta madura, glabra; primeiro antécio neutro ou com flor estaminada; lema (1,9-)2,1-2,6(-3,3) mm compr., ápice agudo a acuminado, 7-11-nervado, glabro; pálea ausente ou presente, então (1,3-)1,5-2,4(-2,7) mm compr., lanceolada à elíptica; segundo antécio 1,6-2,0(-2,2) $\times 0,5-1,0(-1,4) \mathrm{mm}$, subcoriáceo, papiloso, palhete a castanho-escuro na maturação, glabro, sem estípite. Estames 3, anteras 0,7-1,0 mm compr., alaranjadas. Cariopse 0,8-1,1×0,2-0,4 mm, lanceolada, castanha, hilo oval ou oboval.

Material selecionado: BRASIL. Alagoas: Matriz de Camaragibe, 13/IV/1983, Campelo 2158 (CEN). Amapá: Ferreira Gomes, 28/VIII/1955, Black 55-18525 (UB). Amazonas: Manaus, 21/I/1975, Junk 256 (INPA). Bahia: Juazeiro, 1/X/1997, Paula 3017 (HRB). Ceará: Quixadá, 27/VI/1955, Black s.n. (EAC1336). Distrito Federal: Brasília, 11/III/1966,
Irwin et al. 13875 (UB). Goiás: Caldas Novas, 24/III/1993, Dias et al. 521 (CEN). Maranhão: s.mun., Santo Antonio, 7/II/1963, Raiva 987 (HST). Mato Grosso: Poconé, 25/VII/1986, Chagas e Silva 1170 (FUEL). Mato Grosso do Sul: Corumbá, 14/XI/1977, Allem \& Vieira 1200 (CEN)*, 30/VII/1986, Rego 691 (COR). Minas Gerais: Itutinga, XII/1994, Gavillanes 5952 (PAMG). Pará: Altamira, 27/VIII/1986, Souza et al. 130 (MG). Paraná: Entre Rios d'Oeste, 26/IX/1996, Roberto 21 (IBGE). Pernambuco: Santa Maria da Boa Vista, 28/VII/1984, Pinto 189/84 (HRB). Piauí: Picos, 8-11/IV/1933, Swallen 4266 (RB, SP). Rio de Janeiro: Petrópolis, s.d., Peixoto s.n. (RB12346). Rio Grande do Norte: Nova Cruz - Montanhas, 3/VI/1934, Swallen s.n. (SP36177). Rio Grande do Sul: São Lourenço do Sul, 28/XI/1998, Guglieri \& Lerina 3 (ICN)*; Vale do Sol, 18/II/2002, Guglieri et al. 144 (ICN). Roraima: Boa Vista, 26/VIII/1951, Black \& Magalhães 51-13009 (IAN). Santa Catarina: São Bento do Sul, 11/I/2004, Guglieri et al. 231 (ICN). São Paulo: São Paulo,VI/1984, Hashimoto 10728 (SP). Tocantins: Caseara, Parque Estadual de Cantão, 22/I/2000, Nogueira \& Richter 751 (IBGE).

Distribuição geográfica e habitat: Estados Unidos, México, Caribe, Panamá e América do Sul. No Brasil encontra-se amplamente distribuída, geralmente em campos úmidos ou inundáveis, brejos e margens de cursos d'água. Encontrada também em margens de estradas, desde que o local apresente um considerável grau de umidade. Kissmann (1997) considerou Panicum dichotomiflorum como infestante agressiva em áreas úmidas, como em lavouras de arroz.

Allem \& Valls (1987) mencionaram a ocorrência de Panicum dichotomiflorum no pantanal matogrossense, especialmente nas regiões de Cáceres e Paiaguás. Filgueiras (1995) não citou esta espécie para Goiás e Tocantins, no entanto, a sua ocorrência foi confirmada nestes estados.

Plantas de Panicum dichotomiflorum estão geralmente associadas a ambientes úmidos, assim como $P$. aquaticum, $P$. gouinii, $P$. pedersenii e $P$. repens, com as quais é morfologicamente semelhante. Diferencia-se pelos caracteres discutidos anteriormente em $P$. aquaticum.

3. Panicum elephantipes Trin., Gram. panic.: 206. 1826. Tipo: Brasil, Guaporé, 1829, G.H. von Langsdorff s.n. [holótipo: LE-TRIN-0692.01!; isótipos: B!, BAA-1825! (fragm.), US-974407! (fragm.)]. 
P. fistulosum Hochst. ex Steud., Syn. pl. glumac. 1: 71. 1853. Tipo: Suriname, s.d., A. Kappler 1434 [holótipo: P!; isótipos: FI, G!, MO!, S, US-80616! (fragm.)].

Fig. 10-13

Plantas perenes, 90,0-140,0 cm, decumbentes, radicantes nos nós inferiores, com rizomas finos, de 0,2-0,4 cm de diâmetro, entrenós curtos, com 0,5-1,0 cm compr., não escamosos; colmos com aerênquima; nós escuros, glabros. Prefoliação convoluta. Bainhas foliares glabras, margem glabra; colo glabro. Lâminas foliares $(5,0-) 15,0-40,0(-50,0) \times(0,4-) 0,6-1,5(-2,5) \mathrm{cm}$, lineares a linear-lanceoladas, planas ou involutas, base atenuada a arredondada; faces abaxial e adaxial glabras; margens lisas ou escabras, tricomas longos ausentes ou presentes, macios, tuberculados ou não, junto à lígula ou no $1 / 3$ inferior da lâmina. Lígula membranoso-ciliada, 1,5-3,0 mm compr., com tricomas longos atrás, na base da face ventral da lâmina. Panículas (12,0-)20,0-40,5×6,0-12,0(-24,0) cm, laxas,

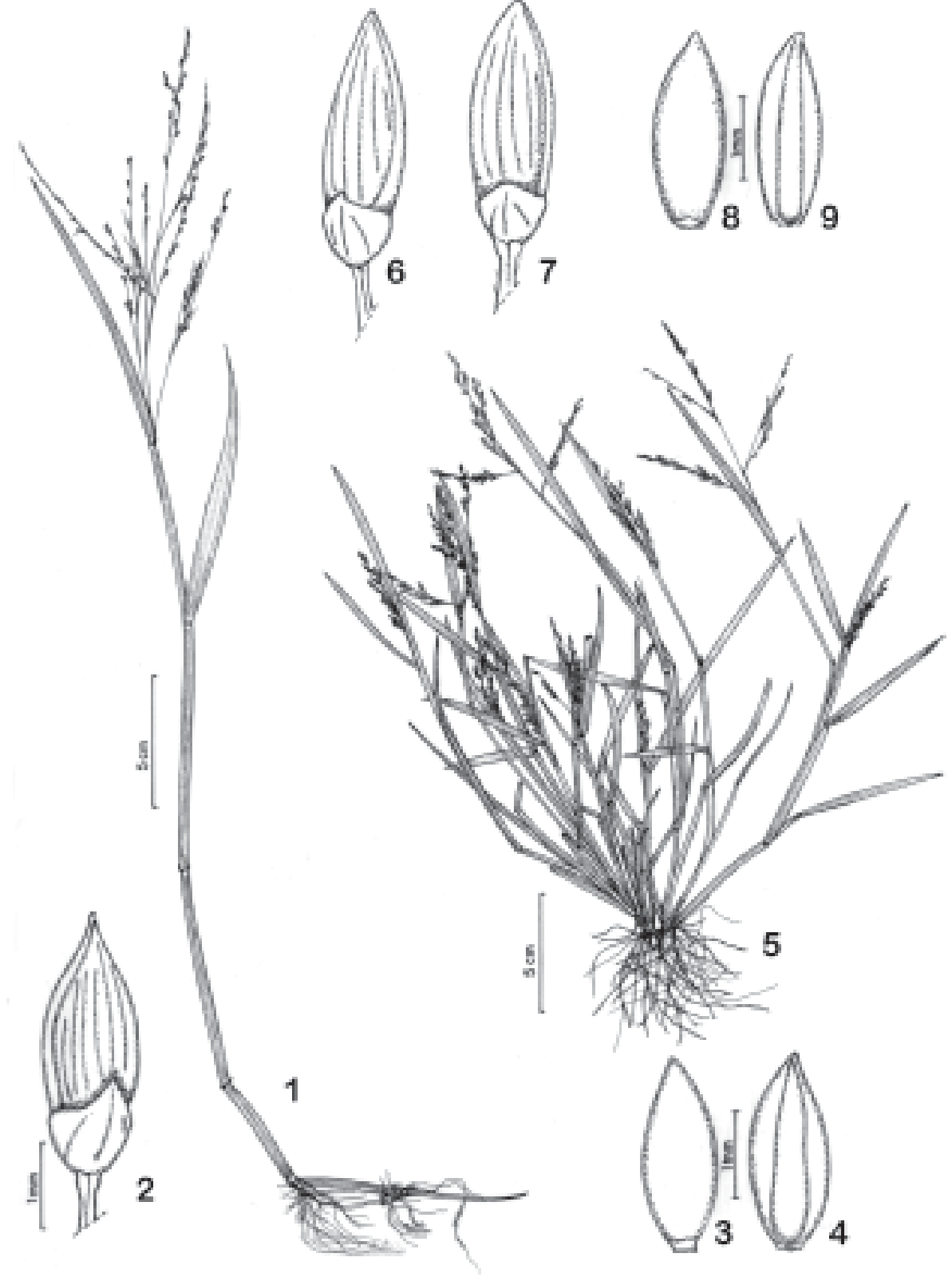

Figuras 1-9. Panicum aquaticum Poir. 1. Hábito. 2. Espigueta, vista lateral. 3. Segundo antécio, vista do lema. 4. Segundo antécio, vista da pálea (Kappel \& Froner s.n., RSPF5193). P. dichotomiflorum Michx. 5. Hábito. 6. Espigueta, vista lateral. 7. Espigueta, vista frontal. 8. Segundo antécio, vista do lema. 9. Segundo antécio, vista da pálea (Swallen 4266, RB). 
ramos inferiores verticilados ou alternos, divergentes do eixo principal; axilas glabras; ráquis escabra; pedicelos escabros; panículas axilares ausentes. Espiguetas (3,7-)4,6-5,4×0,8-1,1 mm, estreitolanceoladas, com dois antécios; glumas e lema do primeiro antécio palhetes ou esverdeados, com manchas vináceas; gluma inferior (1,2-)1,5-1,8 mm compr., 1/4-1/3 do comprimento da espigueta, ápice agudo a acuminado, 3-nervada, glabra; gluma superior (3,6-)4,5-5,3 mm compr., ápice agudo a acuminado, 5-7nervada, persistente na espigueta madura, glabra; primeiro antécio neutro; lema (3,5-)4,4-5,2 mm compr., ápice agudo a acuminado, 7-nervado, glabro; pálea ausente; segundo antécio (3,4-)4,0-4,3×(0,5-)0,8-1,0 mm, subcoriáceo, não papiloso, palhete na maturação, glabro, sem estípite. Estames 3, anteras 1,6-2,1 mm compr., alaranjadas. Cariopse 1,7-2,0×0,6-0,9 mm, elipsóide, palhete a castanha, hilo elíptico.

Material selecionado: BRASIL. Amazonas: Manaus, 2/IV/1975, Yunk 314 (SP). Amapá: Mazagão, s.d, Rabelo et al. 2228 (HAMAB). Distrito Federal: Brasília, XI/1988, Zuloaga 3831 (SI). Mato Grosso: Poconé, 11/IV/1984, Paula 1745 (UB). Pará: Oriximiná, 12/IX/1980, Cid et al. 2419 (INPA). Rio de Janeiro: Macaé, 13/X/1967, Strong 1348 (SI). Rio Grande do Sul: Porto Alegre, Ilha da Pintada, 12/III/2003, Guglieri 188 (ICN)*, Ilha do Marinheiros, 14/IV/1999, Longhi-Wagner et al. 6098 (ICN)*; s.mun., Vieira, 11/IX/1984, Perazzolo s.n. (HURG795). Rondônia: Guajará-Mirim, 4/VI/1952, Black \& Cordeiro 52-14698 (R). Roraima: s.mun., rio Mucajaí, 20/IX/1986, Menezes s.n. (R160760).

Distribuição geográfica e habitat: México, América Central e América do Sul. A espécie é relativamente comum no Brasil e ocorre em alguns estados das regiões Norte, Centro-Oeste, Sudeste e Sul, em margens de cursos d'água, campos inundáveis e brejos. São facilmente reconhecidas, em seu ambiente natural, pelos colmos flutuantes, com aerênquima, presos à margem de cursos d'água.

No Estado do Mato Grosso, a maioria dos registros é procedente de Poconé, o que concorda com Allem $\&$ Valls (1987), os quais mencionaram que esta espécie é uma das principais forrageiras nativas do planalto e do pantanal mato-grossense e adquire grande importância nos pantanais de Poconé e Barão do Melgaço.

4. Panicum gouinii E.Fourn., Mexic. pl. 2: 28. 1886. Tipo: México, Veracruz, VII.1867, Gouin 4 (holótipo: P!; isótipos: BAA! (fragm.), US-80682! (fragm.). Fig. 14-17
Plantas perenes, 18,0-80,0 cm, decumbentes, radicantes nos nós inferiores, com rizomas grossos, de 0,5-0,6 cm de diâmetro, entrenós curtos, com 0,5-1,0 cm compr., escamosos; colmos sem aerênquima; nós claros ou escuros, glabros ou pilosos, tricomas esparsos a densos. Prefoliação convoluta. Bainhas foliares glabras ou pilosas, tricomas não tuberculados, subdensos a densos, margem glabra ou pilosa; colo glabro ou piloso, tricomas esparsos a subdensos. Lâminas foliares $(3,0-) 6,0-18,0(-22,5) \times 0,1-0,3(-0,5) \mathrm{cm}$, lineares, involutas, raramente planas, base atenuada; face abaxial glabra; face adaxial glabra ou pilosa, tricomas não tuberculados, esparsos a densos; margens lisas ou escabras, tricomas longos ausentes. Lígula membranoso-ciliada, (0,3-)0,5-1,5 mm compr., sem tricomas longos atrás na base da face ventral da lâmina. Panículas (4,0-)5,5-15,0×1,0-6,0 cm, subcontraídas, mais raramente laxas, ramos inferiores alternos, divergentes do eixo principal; axilas glabras; ráquis glabra ou escabra; pedicelos glabros ou escabros; panículas axilares ausentes. Espiguetas 2,5-3,3× 0,7-1,1(-1,4) mm, lanceoladas a ovóide-lanceoladas, com dois antécios; glumas e lema do primeiro antécio palhetes, com ou sem manchas vináceas; gluma inferior (1,0-)1,2-2,0 mm compr., 1/3-1/2 do comprimento da espigueta, ápice agudo, 1-7-nervada, glabra; gluma superior 2,4-3,0 mm compr., ápice agudo, 9-11-nervada, persistente na espigueta madura, glabra; primeiro antécio neutro ou com flor estaminada; lema 2,5-3,2 mm compr., ápice agudo, 9-11-nervado, glabro; pálea presente, 2,0-2,5 mm compr., lanceolada; segundo antécio 1,7-2,2×0,6-1,0 mm, subcoriáceo, papiloso, palhete a castanho na maturação, glabro, sem estípite. Estames 3, anteras 0,9-1,3 mm compr., alaranjadas. Cariopse 1,5×0,8 mm, elipsóide, castanha, hilo elíptico.

Material selecionado: BRASIL. Bahia: Morro do Chapéu, 28/VI/1983, Coradin et al. 6205 (CEN). Ceará: Sobral, 12/III/1945, Black \& Avelino 114C (UB). Distrito Federal: Brasília, Santuário da Vida Silvestre do Riacho Fundo, 24/III/1999, Rodriguesda-Silva 119 (UB). Pará: Ilha do Mosqueiro, 14/X/1971, Oliveira 5893 (IAN). Minas Gerais: Diamantina, 10-12/IV/1979, Burman 457 (SP). Paraná: Curitiba, 27/V/1985, Sbalchiero 131 (UPCB)*; São José dos Pinhais, 21/II/1984, Hatschbach 47654 (MBM). Rio Grande do Sul: Rio Grande, 20/IV/1985, Pedralli et al. s.n. (HURG1065)*; Torres, 18/XI/1999, Guglieri 107 (ICN). Santa Catarina: Balneário Camboriú, 16/I/1983, Hatschbach 46653 (MBM); Sombrio, 9/V/1945, Reitz 1694 (IAN)*. São Paulo: Cananéia, 
15/II/1965, Clayton \& Eiten 4687 (SP).

Distribuição geográfica e habitat: México, Caribe, Brasil, Argentina e Uruguai. No Brasil, tem ocorrência confirmada em alguns estados das regiões Norte, Nordeste, Sudeste e Sul, sendo mais comum nesta última. Cresce em campos úmidos e inundáveis, margens de cursos d'água, brejos, baixadas, capões, matas ciliares e margens de estradas (locais úmidos) e pode atuar como invasora de gramados e lavouras.

Panicum gouinii ocupa o mesmo ambiente e assemelha-se morfologicamente a $P$. aquaticum, $P$. dichotomiflorum, P. pedersenii e $P$. repens. Diferencia-se pelos caracteres comentados em $P$. aquaticum.

5. Panicum pedersenii Zuloaga, Hickenia 1(27): 149. 1978. Tipo: Argentina, Corrientes, Depto. Mburucuya, Estancia Santa Maria, 6/III/1961, Pedersen 5868 (holótipo: BAA!; isótipo: Herb. Pedersen!).

Fig. 18-21

Plantas perenes, 55,0-130,0 cm, decumbentes, radicantes nos nós inferiores, com rizomas finos, de

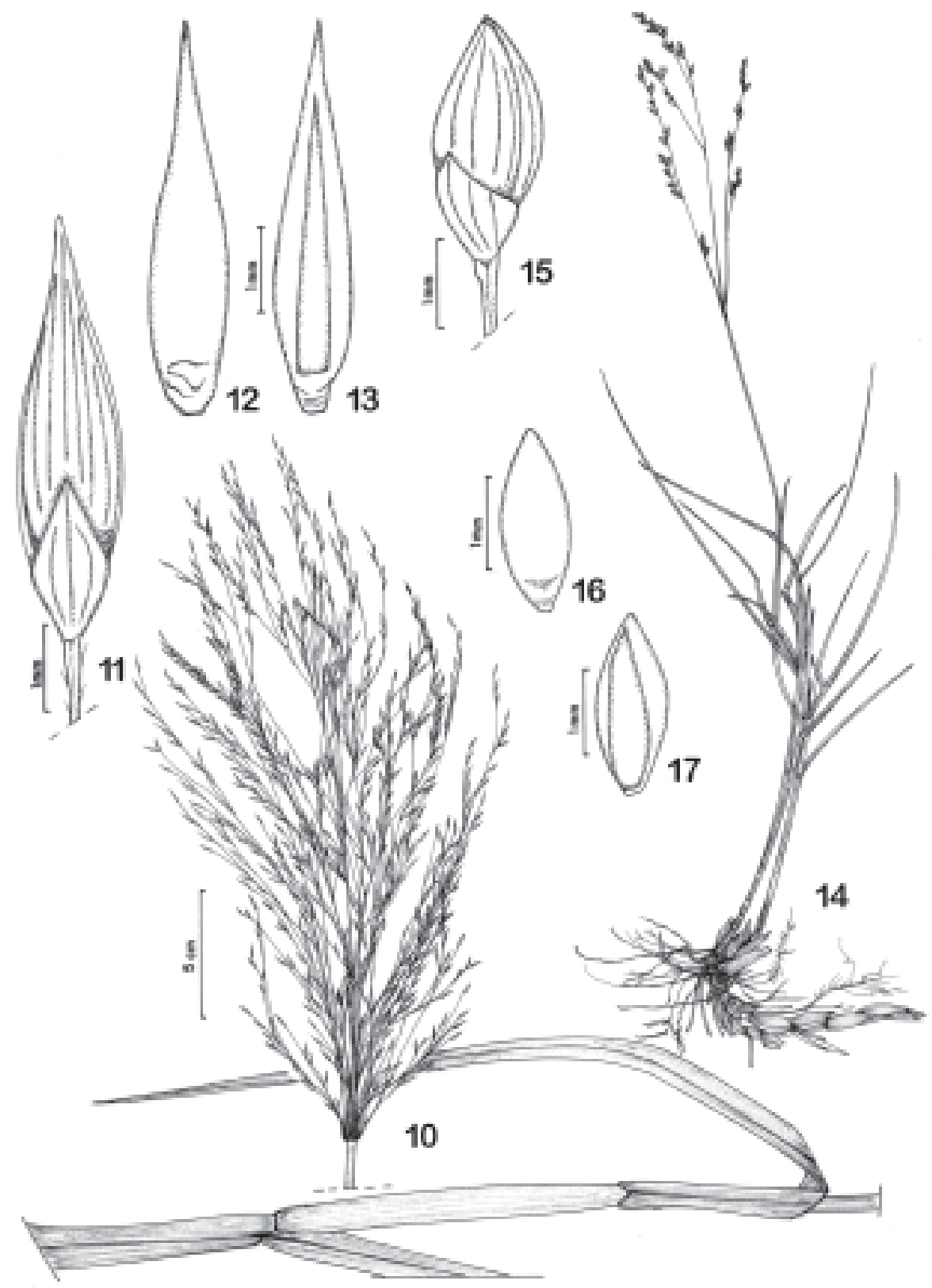

Figura 10-17. Panicum elephantipes Trin. 10. Inflorescência e colmo. 11. Espigueta, vista frontal. 12. Segundo antécio, vista do lema. 13. Segundo antécio, vista da pálea (Perazzolo s.n., HURG795). P. gouinii E. Fourn. 14. Hábito. 15. Espigueta, vista lateral. 16. Segundo antécio, vista do lema. 17. Segundo antécio, vista da pálea (Hatschbach 47654, MBM). 
0,2-0,4 cm de diâmetro, entrenós curtos, com 1,0-2,3 cm compr., não escamosos; colmos sem aerênquima; nós escuros, glabros. Prefoliação convoluta. Bainhas foliares glabras ou pilosas, tricomas não tuberculados, densos, margem pilosa; colo glabro. Lâminas foliares 9,0-30,0×(0,2-)0,4-0,7(-1,0) cm, lineares, planas ou involutas, base atenuada; faces abaxial e adaxial glabras ou pilosas, tricomas não tuberculados, esparsos a densos; margens lisas ou escabras, tricomas longos ausentes. Lígula membranoso-ciliada, (0,4-)1,0-1,2 mm compr., sem tricomas longos atrás na base da face ventral da lâmina. Panículas (8,0-)12,0-22,0×1,0-3,0 cm, laxas a subcontraídas, ramos inferiores alternos ou verticilados, divergentes ou adpressos ao eixo principal; axilas glabras; ráquis glabra ou escabra; pedicelos escabros; panículas axilares ausentes. Espiguetas 3,0-3,3×1,0-1,4 mm, lanceoladas, com dois antécios; glumas e lema do primeiro antécio palhetes ou esverdeados, com ou sem manchas vináceas; gluma inferior 0,9-1,3 mm compr., 1/4-3/4 do comprimento da espigueta, ápice obtuso, 5-7-nervada, glabra; gluma superior 3,0-3,2 mm compr., ápice agudo, 9-11-nervada, persistente na espigueta madura, glabra; primeiro antécio com flor estaminada; lema 2,9-3,1 mm compr., ápice agudo, 7-9-nervado, glabro; pálea presente, 2,4-3,0 mm compr., elíptica ou oval-lanceolada; segundo antécio 2,1-2,4×0,9-1,0 mm, subcoriáceo, papiloso, palhete na maturação, glabro, com estípite de 0,2(-0,4) mm compr. Estames 3, anteras 1,0-1,6 mm compr., alaranjadas. Cariopse não vista.

Material selecionado: BRASIL. Alagoas: Porto Calvo, 18/V/1983, Campelo 2177 (CEN). Bahia: Salvador, Parque Metropolitano de Pituaçu, 14/II/1998, Costa \& Conceição 139 (HRB). Distrito Federal: Brasília, 14/I/1997, Vasconcelos et al. 29 (HUEFS). Mato Grosso: Poconé, 29/X/1981, da Silva 388 (UFMT). Mato Grosso do Sul: Eldorado, 14/III/1985, Hatschbach et al. 48998 (MBM). Minas Gerais: Sete Lagoas, 11/VIII/1998, Macedo 2866 (PAMG). Paraná: Entre Rios d'Oeste, 24/IV/1997, Souza 34 (IBGE). Rio de Janeiro: Magé, 12/I/2001, s.col. (PAMG54659). Rio Grande do Sul: Eldorado do Sul, I/1965, Kappel s.n. (RSPF3914)*; São Leopoldo, s.d., Dutra 588 (ICN); Porto Alegre, Morro do Côco, 31/VII/1979, Bueno 1594 (ICN)*. São Paulo: São Paulo, Reserva Biológica do Parque Estadual das Fontes do Ipiranga, 7/VI/1982, Sendulsky 1896 (SP).

Distribuição geográfica e habitat: Brasil, Paraguai e Argentina. Esta espécie é pouco comum no Brasil, onde ocorre em brejos, margens de lagos e cursos d'água, restingas e em locais úmidos à margem de estradas. Exemplares desta espécie foram coletados em cultura de cana-de-açúcar e em gramados, onde atuavam como invasores. Embora não tenha sido citada para o Paraná, Bahia e São Paulo por Renvoize (1988), Renvoize (1984) e Zuloaga et al. (2001), respectivamente, esta espécie foi constatada nestes estados.

Panicum pedersenii ocorre em ambientes similares e assemelha-se morfologicamente a $P$. aquaticum, $P$. dichotomiflorum, $P$. gouinii e $P$. repens, das quais diferencia-se pelos caracteres discutidos em $P$. aquaticum.

6. Panicum repens L., Sp. pl. 1: 87. 1762. Tipo: Espanha, Alstroemer s.n. (lectótipo: LINN-80.74, designado por Hitchc. \& Chase, Contr. U.S. Natl. Herb. 15: 85. 1910).

P. nitidum Hack. \& Arechav., Anales Mus. Nac. Montevideo 1: 131. 1894. nom. illeg. hom. [non $P$. nitidum Lam., 1791 = Dichanthelium dichotomum var. nitidum (Lam.) Le Blond)].

Fig. 22-25

Plantas perenes, (28,0-)45,0-100,0(-150,0) cm, decumbentes, radicantes ou não nos nós inferiores, às vezes eretas, com rizomas finos, de 0,2-0,3 cm de diâmetro, entrenós longos, com 0,5-1,5 cm compr., não escamosos; colmos sem aerênquima; nós escuros, glabros ou pilosos, tricomas esparsos. Prefoliação convoluta. Bainhas foliares glabras, pilosas ou hirsutas, tricomas tuberculados, esparsos a densos, margem glabra ou pilosa; colo glabro ou piloso. Lâminas foliares $6,5-23,0(-32,0) \times 0,2-0,5(-0,7) \mathrm{cm}$, linear-lanceoladas, planas, base atenuada a arredondada; faces abaxial e adaxial glabras, pilosas ou hirsutas, tricomas tuberculados ou não, esparsos a densos; margens lisas ou escabras, tricomas longos presentes, macios, tuberculados, no 1/10-1/5 inferior da lâmina. Lígula membranoso-ciliada, 0,4-1,0 mm compr., com ou sem tricomas longos atrás, na base da face ventral da lâmina. Panículas 4,5-24,0×1,0-8,0 cm, laxas a subcontraídas, ramos inferiores alternos, divergentes do eixo principal; axilas glabras; ráquis glabra ou escabra; pedicelos escabros; panículas axilares ausentes. Espiguetas 2,4-3,0(-3,3) $\times 0,8-1,5(-1,8) \mathrm{mm}$, lanceoladas a ovóide-lanceoladas, com dois antécios; glumas e lema do primeiro antécio palhetes, sem manchas vináceas; gluma inferior $0,5-1,1(-1,3) \mathrm{mm}$ compr., 1/5-2/5 do comprimento da espigueta, ápice truncado, 1-5-nervada, glabra; gluma superior 2,2-2,7(-3,0) mm compr., ápice agudo, 9-11-nervada, persistente na espigueta madura, glabra; primeiro antécio com flor estaminada; lema 2,2-2,7(-3,0) mm 
compr., ápice agudo, 9-11-nervado, glabro; pálea presente, 1,8-2,3(-2,5) mm compr., oval-lanceolada; segundo antécio 1,9-2,2×(0,6-)0,8-1,0 mm, subcoriáceo, não papiloso, palhete a castanho na maturação, glabro, sem estípite. Estames 3, anteras 1,2 mm compr., alaranjadas. Cariopse não vista.

Material selecionado: BRASIL. Mato Grosso: Poconé, 5/III/1992, Schessl 50392-49/4 (UFMT). Pará: Belém, IAN, 1954, Andrade H-9 (IAN), 29/XI/1956, Black 56-18910 (UB)*. Paraná: Santa Helena, XII/1995, Bini 41 (IBGE). Pernambuco:
Triunfo, 12/IX/1969, Tenório 69-1007 (IPA). São Paulo: Campinas, 29/XI/1938, s.col. (IAC23763), s.col. (IAC23764)*; Piracicaba, III/1995, Zandoval 105 (ESA).

Distribuição geográfica e habitat: Panicum repens é uma espécie originária da Europa, introduzida na América, principalmente na Argentina, para fixação de dunas, e atualmente comporta-se como invasora, embora não muito difundida nos Estados Unidos, Belize, Caribe e Argentina (Zuloaga 1981). Não há registro de sua introdução no Brasil, sendo provável que a

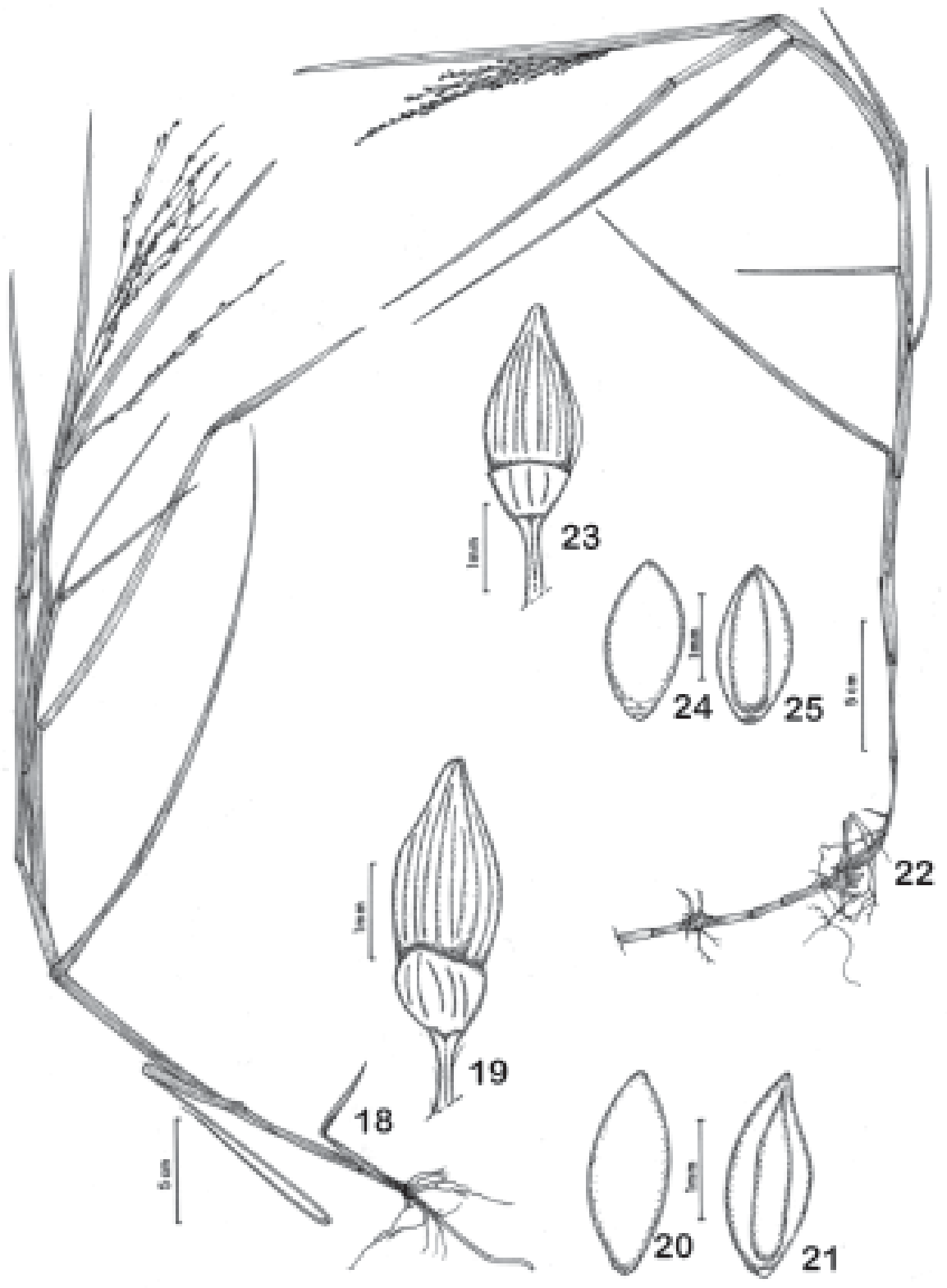

Figuras 18-25. Panicum pedersenii Zuloaga 18. Hábito. 19. Espigueta, vista lateral. 20. Segundo antécio, vista do lema. 21. Segundo antécio, vista da pálea (Dutra 588, ICN). P. repens L. 22. Hábito. 23. Espigueta, vista frontal. 24. Segundo antécio, vista do lema. 25. Segundo antécio, vista da pálea (s.col., IAC23763). 
espécie tenha sido casualmente introduzida no país, onde hoje é naturalizada, e ocorre de forma pouco expressiva em brejos, margens de córregos, campos, e em margens de estradas (locais úmidos).

Smith et al. (1982) mencionaram a ocorrência de Panicum repens no Estado de Santa Catarina. No entanto, o material em que os autores se basearam [Bresolin 11174 (FLOR 4553), 11196 (FLOR 4552); Klein 10069 (FLOR 4269); Klein \& Bresolin 11434(FLOR 4549), 11438 (FLOR 4550), 11443 (FLOR 4551); Reis 43 (FLOR 4621), 44 (FLOR 4622)], trata-se, na realidade, de $P$. gouinii. Sendo assim, no Brasil, o limite sul da espécie, conhecido até o momento, é a região leste do Paraná.

Panicum repens ocorre geralmente em ambientes úmidos, assim como $P$. aquaticum, $P$. gouinii, $P$. dichotomiflorum e $P$. pedersenii, com as quais é morfologicamente semelhante, e distingue-se pelos caracteres mencionados em $P$. aquaticum.

Holm et al. (1977 apud Zuloaga 1981) mencionaram que Panicum repens é uma importante espécie invasora, devido ao rápido crescimento e resistência aos herbicidas. Kissmann (1997) também mencionou que esta espécie é uma invasora de muito difícil erradicação e que ocorre freqüentemente em pomares.

II. Panicum subg. Panicum sect. Virgata Hitchc. $\&$ Chase ex Pilg.

A seção inclui cerca de oito espécies neotropicais (Aliscioni et al. 2003), das quais três ocorrem no Brasil.

Chave para as espécies de Panicum subg. Panicum sect. Virgata ocorrentes no Brasil

1. Lâminas foliares planas; pedicelos escabros, sem tricomas longos; espiguetas 4,0-4,2(-4,4) mm compr.; gluma inferior 9-nervada; gluma superior e lema do primeiro antécio 11-nervados .....

1. Lâminas foliares involutas, mais raramente planas; pedicelos escabros ou não, geralmente com um a vários tricomas longos; espiguetas 2,1-3,4 mm compr.; gluma inferior 3-7-nervada; gluma superior 7-9-nervada; lema do primeiro antécio 5-9-nervado

2. Bainhas foliares mais curtas que os entrenós inferiores, estes aparentes; espiguetas 2,1-2,6(-2,8) mm compr. 9. P. tricholaenoides

2. Bainhas foliares mais longas que os entrenós inferiores, cobrindo os mesmos; espiguetas 2,4-3,4 mm compr. 8. P. glabripes

Foi constatada a ocorrência de Panicum virgatum L. no Brasil com base exclusivamente em exemplares coletados em áreas de cultivo nos Estados de São Paulo, Bahia e Pará, e por esta razão, não foi incluída no presente trabalho. Panicum virgatum é perene, rizomatosa e ereta. Apresenta lâminas foliares linearlanceoladas de 3,0-15,0 cm compr., panícula laxa, 15,0-55,0 cm compr.; espiguetas 3,5-3,8 mm compr., glabras, e segundo antécio palhete a castanho na maturação. Esta espécie ocorre no Canadá, Caribe, México e Estados Unidos.

7. Panicum altum Hitchc. \& Chase, Contr. U.S. Natl. Herb. 17(6): 488. 1915. Tipo: Panamá, Point Chamé, moist sandy soil, near sea beach, growing in large masses, the bases straggling and tangled, 18.IX.1911, A.S. Hitchcock 8167 [holótipo: US-693326!; isótipos: F!, G!, K, MO-848899!, NY!, P!, W!].

Fig. 26-29

Plantas perenes, ca. $127,0 \mathrm{~cm}$, eretas, com rizomas grossos, de 0,4-0,6 cm de diâmetro, entrenós curtos, com 1,0-2,0 cm compr., escamosos; colmos sem aerênquima; nós claros ou escuros, glabros. Prefoliação convoluta. Bainhas foliares mais longas que os entrenós inferiores, cobrindo os mesmos, glabras, margem glabra ou pilosa; colo glabro. Lâminas foliares $13,0-27,0(-40,0) \times 0,4-0,6 \mathrm{~cm}$, lineares a linearlanceoladas, planas, base atenuada; faces abaxial e adaxial glabras; margens lisas ou escabras, tricomas longos ausentes ou presentes, macios e tuberculados, no 1/10 inferior da lâmina. Lígula membranoso-ciliada, 1,0-1,4 mm compr., sem tricomas longos atrás, na base da face ventral da lâmina. Panículas 17,0-19,0× 2,0-3,0 cm, laxas a subcontraídas, ramos inferiores alternos, divergentes do eixo principal; axilas glabras; ráquis glabra ou escabra; pedicelos escabros, sem tricomas longos; panículas axilares ausentes. Espiguetas 4,0-4,2(-4,4) $\times 0,8-1,0 \mathrm{~mm}$, lanceoladas a ovóide-lanceoladas, com dois antécios; glumas e lema do primeiro antécio palhetes a castanhos, sem manchas vináceas; gluma inferior 2,9-3,4(-3,8) mm compr., 2/3-4/5 do comprimento da espigueta, ápice acuminado, 9-nervada, glabra, escabra sobre a nervura central; 
gluma superior 3,8-4,0 mm compr., ápice agudo a acuminado, 11-nervada, persistente na espigueta madura, glabra; primeiro antécio com flor estaminada; lema 3,5-3,8 mm compr., ápice agudo a acuminado, 11-nervado, glabro; pálea presente, 3,0-3,6 mm compr., lanceolada a oval-lanceolada; segundo antécio 2,4-2,8×0,7-1,0 mm, subcoriáceo, papiloso, palhete na maturação, glabro. Estames 2-3, anteras 1,1-1,3 mm compr., violáceas. Cariopse não vista.

Material examinado: BRASIL. Maranhão: Loreto, 20/III/1985, Valls et al. 8433 (CEN, SI)*.

Distribuição geográfica e habitat: México, América Central, Venezuela Guiana, e Brasil, onde está representada por uma única coleta em área de cerrado.

8. Panicum glabripes Döll in Mart., Fl. bras. 2(2): 216. 1877. Tipo: Uruguai, Montevideo, s.d., F. Sellow 130 [holótipo: B!; BAA-1846! (fragm.), US80675! (fragm.)]

P. subjunceum E.Ekman, Ark. Bot. 10(17): 16. 1911. Tipo: Brasil, Paraná, Serrinha, in campo subhumido, 9/XII/1908, P. Dusén 7339 [holótipo: S; isótipos: B!, BAA-1979! (fragm.), SI! (fragm.), US-140033! (fragm.), US-1720197! (fragm.), US-601107!, US81136 (fragm.)].

Fig. 30-33

Plantas perenes, 85,0-160,0 cm, eretas, com rizomas grossos, de 0,6-0,9 cm de diâmetro, entrenós curtos, com (0,5-)1,0-1,7 cm compr., escamosos; colmos sem aerênquima; nós escuros, glabros. Prefoliação convoluta. Bainhas foliares mais longas que os entrenós inferiores, cobrindo os mesmos, glabras, margem glabra ou pilosa; colo glabro. Lâminas foliares $(6,0-) 16,0-35,0(-48,5) \times 0,2-0,6 \mathrm{~cm}$, lineares, involutas, base atenuada; face abaxial glabra; face adaxial pilosa a hirsuta, tricomas não tuberculados, esparsos a densos; margens lisas ou escabras, tricomas longos ausentes ou presentes, macios, no 1/5 inferior da lâmina. Lígula membranoso-ciliada, (0,4-)0,6-1,4(-2,1) mm compr., sem tricomas longos atrás, na base da face ventral da lâmina. Panículas 14,0-24,0×4,0-11,0 cm, laxas a subcontraídas, ramos inferiores alternos, divergentes do eixo principal; axilas glabras; ráquis glabra ou escabra; pedicelos escabros ou não, com um a vários tricomas longos, às vezes ausente; panículas axilares ausentes. Espiguetas 2,4-3,4×0,7-1,0 mm, lanceoladas a ovóide-lanceoladas, com dois antécios; glumas e lema do primeiro antécio palhetes a castanhos, com ou sem manchas vináceas; gluma inferior 1,4-2,6 mm compr., 1/2-3/4 do comprimento da espigueta, ápice agudo a acuminado, 3-5-nervada, glabra, escabra sobre as nervuras ou apenas sobre a nervura central; gluma superior 2,2-3,1 mm compr., ápice agudo a acuminado, 7-nervada, persistente na espigueta madura, glabra; primeiro antécio neutro ou com flor estaminada; lema 2,2-2,6 mm compr., ápice agudo a acuminado, 5-7-nervado, glabro; pálea presente, 1,6-2,5 mm compr., lanceolada a oval-lanceolada; segundo antécio 1,5-2,2×0,7-1,0 mm, subcoriáceo, papiloso, palhete na maturação, glabro. Estames 3, anteras (0,7-)1,1-1,4 mm compr., violáceas. Cariopse $1,5 \times 1,0 \mathrm{~mm}$, largamente elipsóide, castanha, hilo elíptico.

Material selecionado: BRASIL. Mato Grosso do Sul: Corumbá, 14/XI/1977, Allem et al. 1194 (CEN). Minas Gerais: Uberlândia, 24/I/1957, Macedo 4910 (SP). Paraná: São José dos Pinhais, 25/XII/1951, Hatschbach 2648 (SI), 8444 (MBM)*. Rio Grande do Sul: Pelotas, 12/XII/1962, Kappel \& Froner s.n. (RSPF686); São Leopoldo, 15/X/1903, Dutra 632 (ICN)*, s.mun., s.d., Dutra 66 (IAN). Tocantins: Ilha do Bananal, Parque Nacional do Araguaia, 27/III/1999, Mendonça et al. 4057 (SP).

Distribuição geográfica e habitat: Brasil, Argentina e Uruguai. No Brasil é rara e até o momento foi registrada em alguns poucos estados, onde ocorre em campos úmidos, brejos, margens de rios e estradas, e mais raramente em áreas de cerradão. Smith et al. (1982) comentaram que a ocorrência de Panicum glabripes no Estado de Santa Catarina é provável. Os autores citaram o exemplar Reitz \& Klein 1861 (HBR), coletado em Ilhota, como representativo desta espécie e comentaram que o material foi perdido.

Panicum glabripes e P. tricholaenoides são espécies bastante semelhantes pelo porte, hábito, inflorescências e espiguetas. A segunda espécie diferencia-se por apresentar colmos ramificados nos nós superiores, bainhas foliares mais curtas que os entrenós inferiores, estes aparentes, e espiguetas com 2,1-2,6(-2,8) mm de comprimento.

9. Panicum tricholaenoides Steud., Syn. pl. glumac. 1: 68. 1853. Tipo: Uruguai, Ex Herbo. Deloche lectum in Montevideo (holótipo: W!).

P. junceum Nees, Agrostologia brasiliensis, in Mart., Fl. bras. enum. pl. 2: 159. 1829. Tipo: Brasil, Sellow s.n. (holótipo: B). nom. illeg. hom. [non P. junceum Trin., 1826 = Dichanthelium depauperatum (Muhl.) Gould]

Fig. 34-37

Plantas perenes, 74,0-200,0 cm, eretas, com rizomas grossos, de 0,5-0,9 cm de diâmetro, entrenós curtos, com 0,5-1,0 cm compr., escamosos; colmos sem 
aerênquima; nós escuros, glabros ou pilosos, tricomas subdensos a densos. Prefoliação convoluta. Bainhas foliares mais curtas que os entrenós inferiores, estes aparentes, glabras, margem glabra ou pilosa; colo glabro ou piloso, tricomas esparsos. Lâminas foliares 10,0-31,5×0,1-0,7 cm, lineares, involutas, mais raramente planas, base atenuada; face abaxial glabra; face adaxial glabra, pilosa ou hirsuta, tricomas não tuberculados, esparsos a densos; margens lisas ou escabras, tricomas longos ausentes ou presentes, macios, junto à lígula ou no $1 / 5$ inferior da lâmina. Lígula membranoso-ciliada, (0,6-)1,2-1,4 mm compr., sem tricomas longos atrás, na base da face ventral da lâmina.
Panículas (9,5-)12,5-28,0×(2,0-)5,5-15,0(-22,5) cm, laxas a subcontraídas, ramos inferiores alternos, divergentes do eixo principal; axilas glabras; ráquis glabra ou escabra; pedicelos escabros, com um ou vários tricomas longos, às vezes ausentes; panículas axilares ausentes. Espiguetas 2,1-2,6(-2,8)×0,9-1,2 mm, lanceoladas, ovóide-lanceoladas ou ovóides, com dois antécios; glumas e lema do primeiro antécio palhetes, sem manchas vináceas; gluma inferior 1,4-2,0 mm compr., 1/2-3/4 do comprimento da espigueta, ápice agudo a acuminado, 5-7-nervada, glabra, escabra sobre a nervura central; gluma superior 2,1-2,4 mm compr., ápice acuminado, 7-9-nervada, persistente na espigueta

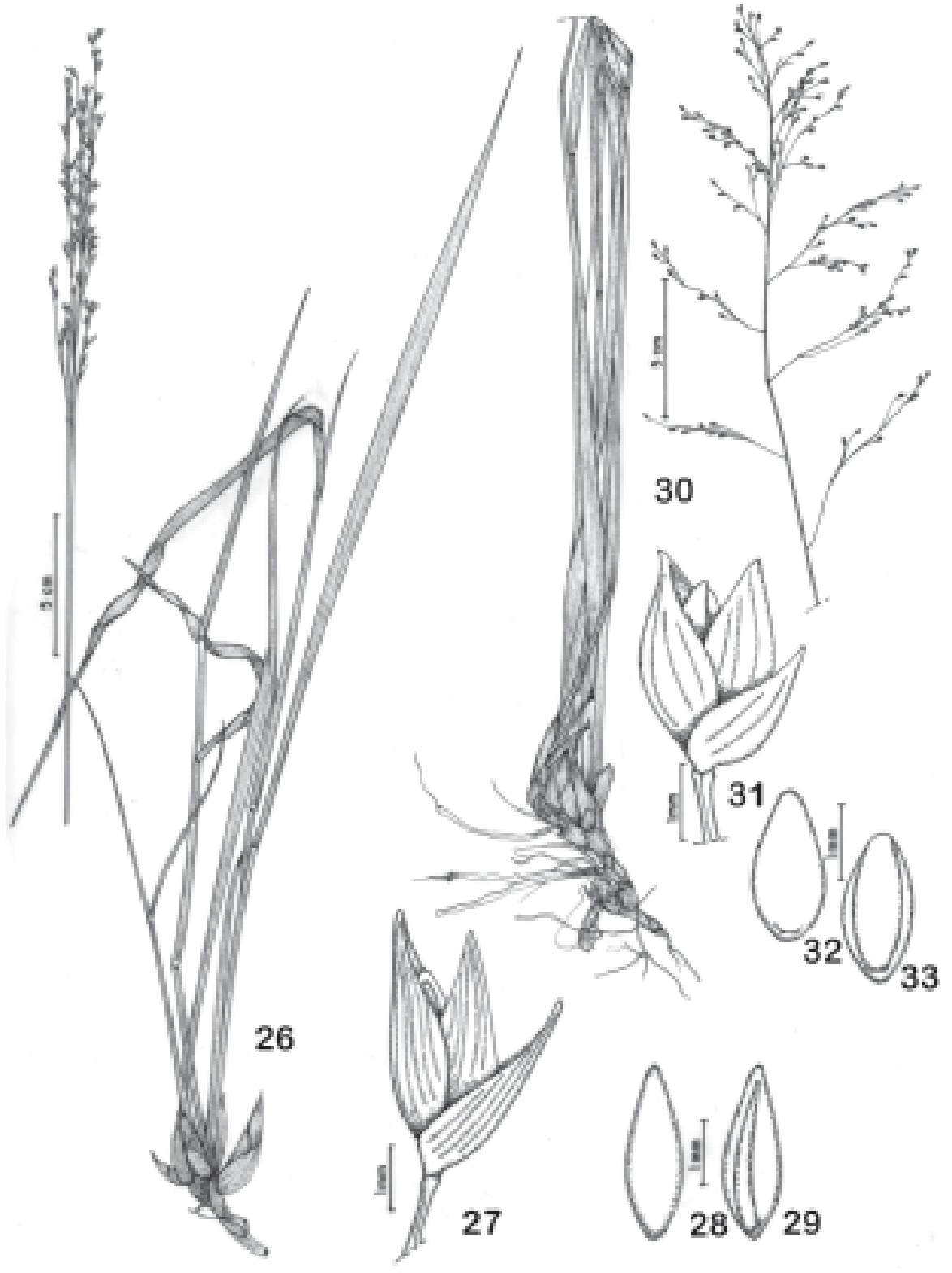

Figuras 26-33. Panicum altum Hitchc. \& Chase 26. Inflorescência e colmos. 27. Espigueta, vista lateral. 28. Segundo antécio, vista do lema. 29. Segundo antécio, vista da pálea (Valls 8433, CEN). P. glabripes Döll 30. Inflorescência e colmos. 31. Espigueta, vista lateral. 32. Segundo antécio, vista do lema. 33. Segundo antécio, vista da pálea (Dutra 66, ICN). 
madura, glabra; primeiro antécio neutro ou com flor estaminada; lema 2,0-2,4 mm compr., ápice agudo a acuminado, 7-9-nervado, glabro; pálea presente, 1,6-1,9 mm compr., elíptica ou oval-lanceolada; segundo antécio 1,6-2,0×0,6-0,9 mm, subcoriáceo, papiloso, castanho na maturação, glabro. Estames 3, anteras 0,8-1,2 mm compr., violáceas. Cariopse $1,2 \times 0,8 \mathrm{~mm}$, elipsóide, castanha, hilo oboval.

Material selecionado: BRASIL. Mato Grosso: Barão do Melgaço, 3/X/1979, Allem \& Vieira 2506 (CEN). Mato Grosso do Sul: Corumbá, 23/X/1979, Comastri Filho 9 (CEN, HEPH); Minas Gerais: Formoso, 5/XII/1997, Alvarenga et al. 1140 (IBGE)*, Perdões, 17/XI/1982, Carvalho et al. s.n. (ESAL13596). Paraná: São José dos Pinhais, 11/I/2004, Guglieri et al. 238 (ICN). Rio Grande do Sul: Cristal, 31'08'40,2"S 052 01'49,5"W, 16/XI/2003, Guglieri et al. 197 (ICN); Guaporé, 11/VI/1952, Black \& Cordeiro 52-14836 (IAN)*. Tocantins: Pium, Ilha do Bananal, Parque Nacional do Araguaia, 21/VI/1979, Silva et al. 282 (SP).
Distribuição geográfica e habitat: Colômbia, Venezuela, Brasil, Bolívia, Paraguai, Argentina e Uruguai. Esta espécie é pouco comum no Brasil, onde foram registradas poucas coletas, distribuídas entre alguns estados, em campos, margens de rios e mais raramente em áreas de campo-cerrado.

Allem \& Valls (1987) destacaram Panicum tricholaenoides, juntamente com Andropogon hypogynus Hack., como as principais espécies não palatáveis dos campos limpos de Miranda, no pantanal mato-grossense.

Panicum tricholaenoides apresenta rizomas profundos e robustos, forma touceiras individuais e esparsas, e ocorre geralmente associada a solos arenosos. Assemelha-se morfologicamente a P. glabripes pelo porte, hábito, inflorescências e espiguetas, e diferencia-se da mesma pelos caracteres já comentados.

Análise do segundo antécio em Microscopia Eletrônica de Varredura (MEV) - Nas espécies de Panicum subg. Panicum estudadas não foram observados

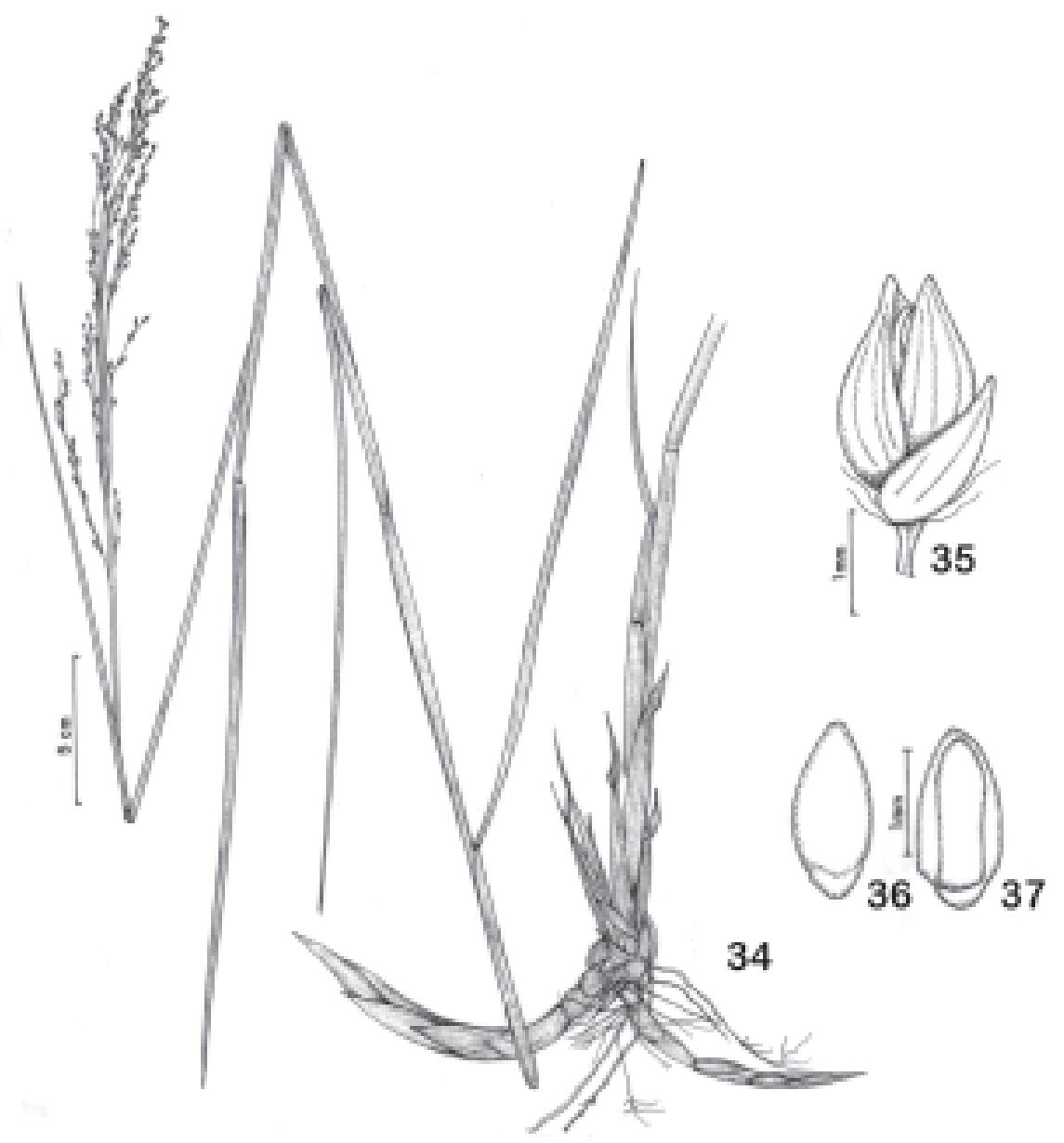

Figuras 34-37. Panicum tricholaenoides Steud. 34. Inflorescência e colmos. 35. Espigueta, vista lateral. 36. Segundo antécio, vista do lema. 37. Segundo antécio, vista da pálea (Comastri Filho 9, CEN). 
tricomas unicelulares uncinados, tricomas microscópicos bicelulares e corpos silicosos, ao contrário de espécies incluídas em seções de outros subgêneros, tais como P. sect. Parviglumia, P. sect. Parvifolia, $P$. sect. Sarmentosa (Zuloaga 1985), P. sect. Stolonifera, $P$. sect. Phanopyrum (atualmente aceita como gênero independente) e $P$. sect. Lorea (Zuloaga \& Sendulsky 1988), bem como em Paspalum subg. Ceresia (Denham et al. 2002), e nos grupos informais Plicatula (R.C. Oliveira, dados não publicados) e Eriantha (Morrone et al. 2004) de Paspalum.

Foi observado que nas espécies de Panicum sect. Dichotomiflora e $P$. sect. Virgata, as quais apresentam segundo antécio subcoriáceo, as margens do ápice do lema envolvem uma porção maior da pálea (Fig. 38, 44), diferentemente das demais espécies de $P$. subg. Panicum, que apresentam antécio coriáceo.

Zuloaga et al. (1992), em seu estudo da superfície do segundo antécio de espécies de Panicum subg. Phanopyryum sect. Laxa, analisaram a forma das paredes anticlinais transversais e longitudinais das células epidérmicas, a qual mostrou-se fortemente ondulada em todas as espécies estudadas. No presente estudo optou-se por também utilizar este caráter para testar seu valor taxonômico.

Os caracteres referentes ao segundo antécio analisados ao MEV e os estados verificados em cada espécie são apresentados na Tab. 2 e comentados a seguir.

\section{Panicum subg. Panicum sect. Dichotomiflora}

A análise do segundo antécio ao MEV separou as espécies desta seção em três grupos distintos, de acordo com a presença, tipo e padrão de distribuição das papilas na pálea.

Panicum repens não apresenta papilas no lema e na pálea do segundo antécio, o que a distingue das demais espécies da seção e a aproxima de $P$. elephantipes, embora sejam bastante diferentes quanto à macromorfologia e habitat. Além disso, nas outras espécies da seção analisadas, as paredes anticlinais da epiderme do lema e da pálea são retas, enquanto em $P$. repens as paredes do lema são retas e as da pálea são onduladas (Fig. 40, 41).

Entre as espécies que apresentam papilas, dois diferentes padrões de distribuição foram observados. Em Panicum gouinii, as papilas estão dispostas irregularmente (Fig. 42), enquanto nas demais espécies estão regularmente distribuídas em fileiras longitudinais (Fig. 38, 39).

Panicum pedersenii apresenta papilas simples apenas no 1/8 apical da pálea, além de um pequeno
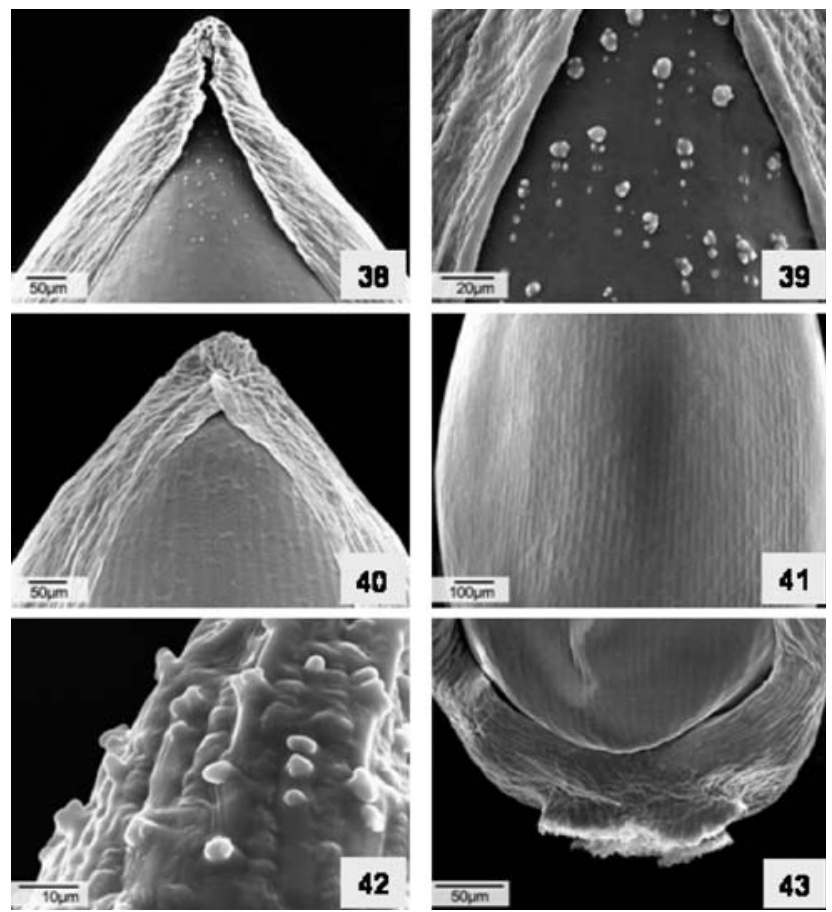

Figuras 38-43. Panicum aquaticum Poir. 38. Ápice da pálea com papilas simples e compostas (Swallen 4414, RB). $P$. dichotomiflorum Michx. 39. Ápice da pálea com papilas simples e compostas (Allem \& Vieira1200, CEN). P. repens L. 40. Pálea sem papilas, e com células epidérmicas de paredes anticlinais onduladas. 41. Lema com células epidérmicas de paredes anticlinais retas (s.col., IAC23764). P. gouinii 42. Ápice da pálea com papilas simples e compostas (Sbalchiero 131, UPCB). P. pedersenii 43. Detalhe do estípite (Bueno 1594, ICN).

estípite de $0,2(-0,4) \mathrm{mm}$ de comprimento na base do segundo antécio, o que não ocorre em nenhuma outra espécie da seção (Fig. 43). Panicum aquaticum e $P$. dichotomiflorum apresentam papilas compostas, com poucas ramificações, no 1/8 apical da pálea, as quais são substituídas por papilas simples em direção à base, até no 1/5 ou 1/3 apical da pálea (Fig. 38, 39). Em $P$. aquaticum, as papilas estão restritas à pálea, enquanto que em $P$. dichotomiflorum podem ocorrer papilas simples, também em fileiras longitudinais, no 1/3 apical do lema. Estas duas espécies ainda podem ser diferenciadas pelo diâmetro relativo das papilas simples e compostas. Em Panicum aquaticum, as papilas simples apresentam 1,1-5,7 mm de diâmetro, e as compostas, 5,1-8,0 mm de diâmetro, enquanto que em $P$. dichotomiflorum, as papilas simples medem 1,1-3,4 mm de diâmetro, e as compostas, 4,0-6,8 mm de diâmetro.

\section{Panicum subg. Panicum sect. Virgata}

Panicum glabripes e P. tricholaenoides assemelham-se pelo hábito, inflorescência e forma das 
Acta bot. bras. 21(4): 785-805. 2007.

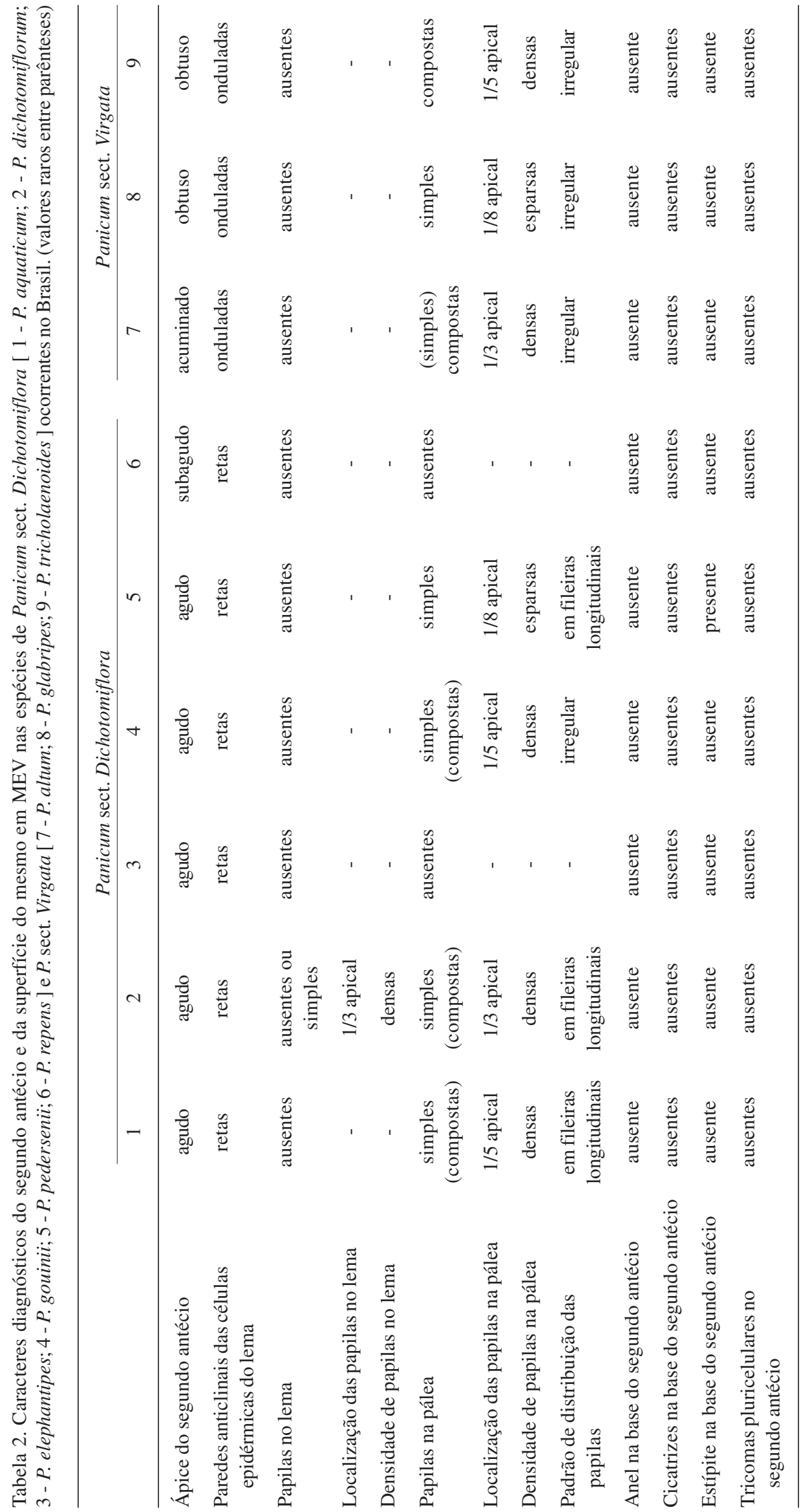


espiguetas, além de ocorrerem no mesmo tipo de ambiente. No entanto, $P$. glabripes apresenta papilas simples esparsas distribuídas irregularmente no $1 / 8$ apical da pálea (Fig. 47), enquanto $P$. tricholaenoides apresenta um grande número de papilas compostas, com muitas ramificações, dispostas irregularmente no 1/5 apical da pálea (Fig. 48).

Por outro lado, o tipo, a densidade e o padrão de distribuição das papilas na pálea de Panicum tricholaenoides assemelha-se ao observado em $P$. altum. Porém, na primeira espécie, o ápice do segundo antécio é obtuso e as papilas compostas apresentam 1,3-2,8 mm de diâmetro, enquanto na segunda, o segundo antécio é acuminado e o diâmetro das papilas compostas varia de (8,1-)10,8-18,9 (Fig. 44, 45, 48). Estas espécies diferem morfologicamente principalmente pelo comprimento das espiguetas e pelo número de nervuras das glumas e do lema do primeiro antécio. Além disso, P. altum foi coletada no Brasil apenas em área de cerrado, enquanto que $P$. tricholaenoides ocorre em campos,
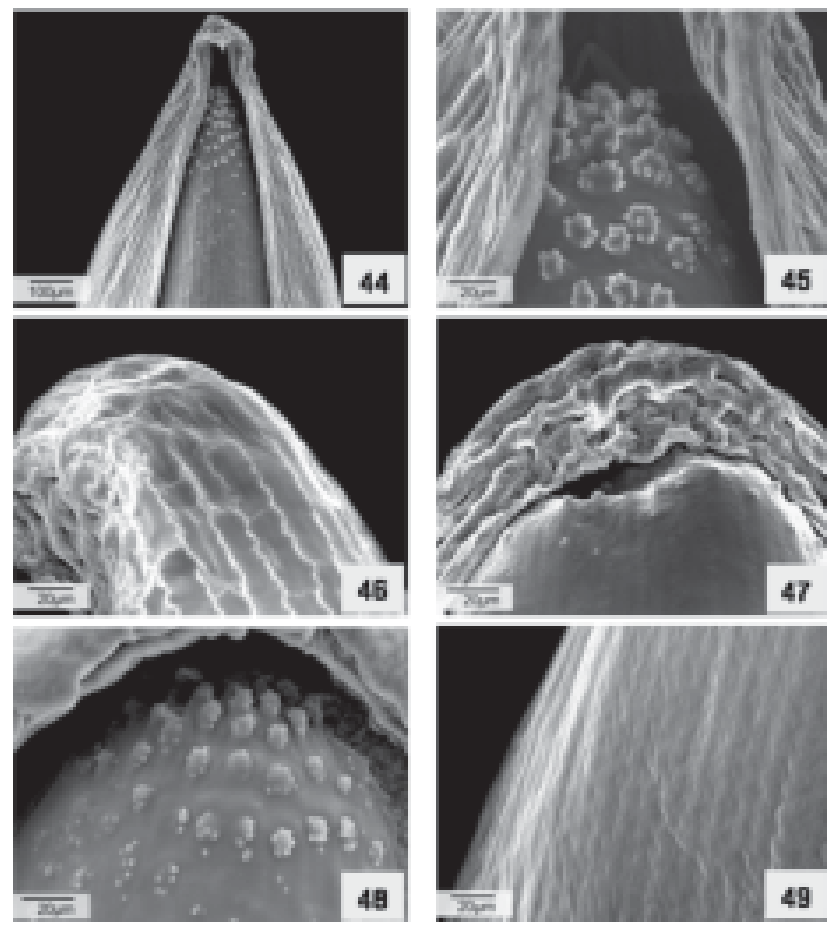

Figuras 44-49. Panicum altum Hitchc. \& Chase 44. Ápice da pálea com papilas simples e compostas. 45 . Detalhe das papilas compostas. 46. Lema com células epidérmicas de paredes anticlinais onduladas (Valls et al. 8433, CEN). P. glabripes Döll 47. Ápice da pálea com papilas simples (Hatschbach 8444, MBM). P. tricholaenoides Steud. 48. Detalhe das papilas compostas. 49. Lema com células epidérmicas de paredes anticlinais onduladas (Alvarenga et al. 1140, IBGE). margens de rios e menos comumente em áreas de campo-cerrado.

As três espécies desta seção apresentam lema com células de paredes anticlinais onduladas, como mostram as figuras 46 e 49 .

\section{Agradecimentos}

Os autores agradecem aos curadores dos herbários revisados, pelo empréstimo de material; aos técnicos do Centro de Microscopia Eletrônica da UFRGS, pelo auxílio na obtenção das fotomicrografias em MEV. A primeira autora agradece ao $\mathrm{CNPq}$, pela bolsa concedida.

\section{Referências bibliográficas}

Aliscioni, S.S.; Giussani, L.M.; Zuloaga, F.O. \& Kellogg, E.A. 2003. A molecular phylogeny of Panicum (Poaceae: Paniceae). Test of monophyly and phylogenetic placement within the Panicoideae. American Journal of Botany 90(5): 796-821.

Allem, A.C. \& Valls, J.F.M. 1987. Recursos forrageiros nativos do pantanal mato-grossense. Empresa Brasileira de Pesquisa Agropecuária. Centro Nacional de Recursos Genéticos, Brasília.

Blake, S.T. 1958. New criteria for distinguishing genera allied to Panicum (Gramineae). Proceedings of the Royal Society of Queensland 70(3): 15-18.

Bridson, G.D.R. \& Smith, E.R. 1991. Botanico-PeriodicumHuntianum. Pittsburgh, Carnegie Mellon University.

Brummitt, R.K. \& Powell, C.E. 1992. Authors of plant names. Kew, The Royal Botanic Gardens.

Clark, C.A. \& Gould, F.W. 1975. Some epidermal characteristics of paleas of Dichanthelium, Panicum and Echinochloa. American Journal of Botany 62(7): 743-748.

Clayton, W.D. \& Renvoize, S.A. 1986. Genera Graminum. Grasses of the world. London, Her Majesty's Stationery Office.

Denham, S.S.; Zuloaga, F.O. \& Morrone, O. 2002. Systematic revision and phylogeny of Paspalum subgenus Ceresia (Poaceae: Panicoideae: Paniceae). Annals of the Missouri Botanical Garden 89(3): 337-199.

Döll, J.C. 1877. Gramineae II. In: C.F.P. von Martius (Ed.). Flora Brasiliensis. Monachii, F. Fleischer.

Filgueiras, T.S. 1995. Gramineae (Poaceae). Pp. 19-24. In: J.A. Rizzo. Flora dos Estados de Goiás e Tocantins. Goiânia, Universidade Federal de Goiás.

Gould, F.W. 1974. Nomenclatural changes in the Poaceae. Brittonia 29: 59-60.

Guglieri, A. \& Longhi-Wagner, H.M. 2000. Panicum (Gramineae - Paniceae). Flora Ilustrada do Rio Grande do Sul - 26. Boletim do Instituto de Biociências/UFRGS 59: 1-163. 
Häfliger, E. \& Scholz, H. 1980. Panicoid grass weeds. Grass weeds 1. Switzerland, Ciba-Geigy.

Holmgren, P.K. \& Holmgren, N.H. 2005. Index Herbariorum. [http://www.nybg.org/bsci/ih/ih.html]

Kissmann, K.G. \& Groth, D. 1997. Plantas infestantes e nocivas. São Paulo, BASF

Morrone, O.; Denham, S. \& Zuloaga, F. 2004. Revisión taxonómica del gênero Paspalum grupo Eriantha (Poaceae, Panicoideae, Paniceae). Annals of the Missouri Botanical Garden 91: 225-246.

Nees, C.G. 1829. Agrostologia brasiliensis v.2, pr. 1, Pp. 96-263. In: C.F.P. von Martius (ed.). Flora Brasiliensis. J.G. Cottae, Stuttgartiae \& Tubingae.

Raddi, G. 1823. Agrostographia brasiliensis. Bertini, Lucca.

Radford, A.E.; Dickison, W.C.; Massey, J.R. \& Bell, C.R. 1974. Vascular plant systematics. New York, Harper \& Row.

Renvoize, S.A. 1984. The grasses of Bahia. Kew, Royal Botanic Gardens.

Renvoize, S.A. 1988. Hatschbach's Paraná grasses. Kew, Royal Botanic Gardens.

Simon, B.K. \& Jacobs, S.W. 2003. Megathyrsus, a new generic name for Panicum subgenus Megathyrsus. Austrobaileya 6(3): 571-574.

Smith, L.B.; Wasshausen, D.C. \& Klein, R.M. 1982. Gramineae. Flora Ilustrada Catarinense (gram.): 633-756.

Stafleu, F.A. \& Cowan, R.S. 1976-1988. Taxonomic literature: a selective guide to botanical publications and collections with dates, commentaries and types. 2 ed. v.1-6, Scheltema \& Hoelkema, Utrecht.

Watson, L. \& Dallwitz, M.J. 1992. The grass genera of the world. Cambridge, University Press.

Zuloaga, F.O. 1981. El género Panicum (Gramineae) en la República Argentina. II. Darwiniana 23(1): 233-256.

Zuloaga, F.O. 1985. El género Panicum L. sección Parviglumia. Darwiniana 26: 353-369.

Zuloaga, F.O. 1987a. Systematics of New World species of Panicum (Poaceae: Paniceae). Pp. 287-306. In: T.R. Soderstrom (ed.). Grass Systematics and Evolution. Washington, Smithsonian Institution Press.
Zuloaga, F.O. 1987b. A revision of Panicum subgenus Panicum section Rudgeana (Poaceae: Paniceae). Annals of the Missouri Botanical Garden 74(3): 463-478.

Zuloaga, F.O.; Ellis, R.P. \& Morrone, O. 1992. A revision of Panicum subgenus Phanopyrum section Laxa (Poaceae: Panicoideae: Paniceae). Annals of the Missouri Botanical Garden 79: 770-818.

Zuloaga, F.O.; Ellis, R.P. \& Morrone, O. 1993. A revision of Panicum subgenus Dichanthelium section Dichanthelium (Poaceae: Panicoideae: Paniceae). Annals of the Missouri Botanical Garden 80(1): 119-190.

Zuloaga, F.O.; Guglieri, A. \& Longhi-Wagner, H.M. 2001. Panicum. Pp. 168-190. In: H.M. Longhi-Wagner; V. Bittrich; M.G.L. Wanderley \& G.J. Sheperd (eds.). Poaceae - Flora Fanerogâmica do Estado de São Paulo. v.1. São Paulo, Hucitec.

Zuloaga, F.O. \& Morrone, O. 1996. Revisión de las especies americanas de Panicum subgénero Panicum sección Panicum (Poaceae: Panicoideae: Paniceae). Annals of the Missouri Botanical Garden 83(2): 200-280.

Zuloaga, F.O.; Morrone, O.; Vega, A.S. \& Giussani, L.M. 1998. Revisión y análisis cladístico de Steinchisma (Poaceae: Panicoideae: Paniceae). Annals of the Missouri Botanical Garden 47: 1-178.

Zuloaga, F.O. \& Morrone, O. 2003. Panicum. Pp. 306-441. In: R.J. Soreng \& S.J. Pennington (eds.). Catalogue of New World Grasses (Poaceae): III. Subfamilies Panicoideae, Aristidoideae, Arundinoideae and Danthonioideae. v.46. Washington, Smithsonian Institution.

Zuloaga, F.O.; Saenz, A.A. \& Morrone, O. 1986. El género Panicum (Poaceae: Paniceae) sect. Cordovensia. Darwiniana 27(1-4): 403-455.

Zuloaga, F.O. \& Sendulsky, T. 1988. A revision of Panicum subgenus Phanopyrum section Stolonifera (Poaceae: Paniceae). Annals of the Missouri Botanical Garden 75(2): 420-455 